OPEN ACCESS

Edited by:

Liliane Schoofs,

KU Leuven, Belgium

Reviewed by:

Joao Carlos dos Reis Cardoso,

University of Algarve, Portugal

Takeshi Iwasa,

Tokushima University, Japan

*Correspondence:

Grégoy Y. Bédécarrats gbedecar@uoguelph.ca

Specialty section:

This article was submitted to Neuroendocrine Science,

a section of the journal

Frontiers in Endocrinology

Received: 22 September 2021 Accepted: 02 December 2021 Published: 13 January 2022

Citation:

Bédécarrats GY, Hanlon C and Tsutsui K (2022) Gonadotropin Inhibitory Hormone and lts

Receptor, Potential Key to the Integration and Coordination of Metabolic Status and Reproduction.

Front. Endocrinol. 12:781543. doi: $10.3389 /$ fendo.2021.781543

\section{Gonadotropin Inhibitory Hormone and Its Receptor: Potential Key to the Integration and Coordination of Metabolic Status and Reproduction}

\author{
Grégoy Y. Bédécarrats ${ }^{1 *}$, Charlene Hanlon ${ }^{1}$ and Kazuyoshi Tsutsui ${ }^{2}$ \\ ${ }^{1}$ Department of Animal Biosciences, University of Guelph, Guelph, ON, Canada, ${ }^{2}$ Graduate School of Integrated Sciences \\ for Life, Hiroshima University, Higashihiroshima, Japan
}

Since its discovery as a novel gonadotropin inhibitory peptide in 2000, the central and peripheral roles played by gonadotropin-inhibiting hormone $(\mathrm{GnlH})$ have been significantly expanded. This is highlighted by the wide distribution of its receptor $(\mathrm{Gn} H \mathrm{H}-\mathrm{R})$ within the brain and throughout multiple peripheral organs and tissues. Furthermore, as $\mathrm{Gn} \| \mathrm{H}$ is part of the wider RF-amide peptides family, many orthologues have been characterized across vertebrate species, and due to the promiscuity between ligands and receptors within this family, confusion over the nomenclature and function has arisen. In this review, we intend to first clarify the nomenclature, prevalence, and distribution of the $\mathrm{GnlH}-\mathrm{Rs}$, and by reviewing specific localization and ligand availability, we propose an integrative role for $\mathrm{GnlH}$ in the coordination of reproductive and metabolic processes. Specifically, we propose that $\mathrm{GnIH}$ participates in the central regulation of feed intake while modulating the impact of thyroid hormones and the stress axis to allow active reproduction to proceed depending on the availability of resources. Furthermore, beyond the central nervous system, we also propose a peripheral role for $\mathrm{GnlH}$ in the control of glucose and lipid metabolism at the level of the liver, pancreas, and adipose tissue. Taken together, evidence from the literature strongly suggests that, in fact, the inhibitory effect of GnlH on the reproductive axis is based on the integration of environmental cues and internal metabolic status.

Keywords: Gonadotropin inhibitory hormone (GnIH), RF-amide related peptide (RFRP), G-protein coupled receptor (GPCR), reproduction, metabolic control

\section{INTRODUCTION}

Following the initial discovery of gonadotropin-inhibiting hormone $(\mathbf{G n I H})$ in quail over 20 years ago (1), homologues have been identified and characterized in multiple vertebrate species ranging from fish to mammals (for review: 2, 3). Structurally, GnIH and its homologues belong to the broader RF-amide peptides family with a unique LPXRFa (X=L or Q) C-terminal motif. As is the case for many novel peptides, $\mathrm{GnIH}$ was named after its reported inhibitory effects on gonadotropin release in quail. In fact, $\mathrm{GnIH}$ was the first hypothalamic peptide reported to exert an anti- 
gonadotrophic effect in any vertebrate species (1). Specifically, $\mathrm{GnIH}$ was shown to directly inhibit gonadotropin-releasing hormone $(\mathrm{GnRH})$ release via the $\mathrm{GnIH}$ receptor (GnIH-R; 4), as well as downregulate luteinizing hormone beta-subunit ( $\mathrm{LH} \beta$ ) mRNA levels (5) and inhibit its release (1) from the anterior pituitary gland. However, the role of GnIH on folliclestimulating hormone beta-subunit $(\mathrm{FSH} \beta)$ has been more ambiguous, as studies in quail have revealed no impact on mRNA levels (5) or FSH release (1), while both were suppressed in cultured cockerel pituitaries (6). Interestingly, although this effect was further confirmed in other avian species and extensively reviewed (7-11), it is less evident in mammals and remains controversial, especially as it relates to puberty (12). Beyond the reproductive axis, GnIH and its receptor have also been shown to participate in the control of energy homeostasis and nutrient partitioning through regulation of appetite control, glycemia, adipose, thyroid activity, and the stress response. Furthermore, since the GnIH-R in mammals is also activated by neuropeptide FF (NPFF), it has been shown to modulate nociception, although via activation by NPFF rather than $\mathrm{GnIH}$ (13). In this review, based on tissue distribution, cellular localization, and ligand availability, we explore the integrative neuroendocrine function of $\mathrm{GnIH}$ and its receptor to coordinate reproduction and energy homeostasis in response to multiple internal and external cues.

\section{NOMENCLATURE OF GnIH-R AND ITS LIGANDS}

Throughout the literature, while GnIH was originally named for its identified role in quail (1), orthologs in mammalian species are commonly annotated as LPXRFa peptides or RFamiderelated peptides (RFRPs), specifically RFRP-3 (14). Additional annotations also used in the literature include neuropeptide VF (NPVF) and neuropeptide SF (NPSF) (15, 16). Similarly, receptors are often named after their known ligands, or when the ligand is unknown, based on the receptor type, genomic, and phylogenic information. In the case of RFamide peptides, this is further complicated by the promiscuity between receptors and ligands (for review: 17). As a result, non-avian GnIH-Rs are also referred to as Neuropeptide-FF receptor 1 (NPFF-R1) (13), receptor OT7T022 (15), and RFRP-R (7). In addition, based on the nomenclature of $G$ protein-coupled receptors (GPR), the GnIH-R is known as GPR147 (18). In fact, despite the confusing nomenclature surrounding GnIH-Rs, it is now well accepted that the primary receptor for GnIH is GPR147, while another candidate, GPR74 (referred to as HLWAR77 or NPFF-R2), which is present in most vertebrates with the exception of fish $(2,19)$, displays a lower affinity for $\mathrm{GnIH}$ and may actually be more specific to $\operatorname{NPFF}(7,8,13,16,20)$. This preferential binding of NPFF to GPR74 also extends to the ligands neuropeptide AF (NPAF) and RFRP-1 (21). Thus, whenever possible for simplicity and coherence, we opted to refer to both ligand and receptors as $\mathrm{GnIH}$ and GnIH-Rs, respectively.

\section{GnIH-Rs STRUCTURE, INTRACELLULAR SIGNALLING AND LIGAND SELECTIVITY}

To date, GnIH-Rs have been cloned or deduced from genomic databases across many vertebrate species (Table 1), including teleosts, aves, and mammals (for review: 2), and although most species possess a single GnIH-R, up to three paralogues have been reported in Goldfish (Carassius auratus; 49), Zebrafish (Danio rerio; 51), common carp (Cyprinus Carpio; 54) and more recently, the Indian Major Carp (Labeo Catla) in which GnIH-R paralogues were shown to belong to the GPR147 group, although forming their own subclade separate from mammalian and avian GPR147 (61). Interestingly, despite these differences in phylogeny, these GnIH-R paralogues have been reported to play similar roles in reproduction, as outlined throughout Table 1.

Like all GPCRs, GnIH-Rs are composed of seven interconnected transmembrane domains along with an $\mathrm{N}$-terminal extracellular and a C-terminal intracellular tail. Following the original identification of the human GnIH-R, transfection studies in Chinese Hamster Ovary $(\mathrm{CHO})$ cells revealed that activation of the receptor results in decreased forskolin-induced cAMP accumulation, while no effect on $\mathrm{Ca}^{2+}$ mediated signaling was observed, suggesting inhibition of adenylyl cyclase, and thus coupling to $G \alpha_{i}$ or $G \alpha_{o}$ (15). The specific inhibition of forskolininduced cAMP accumulation in CHO cells transfected with the human GnIH-R was further confirmed by Mollereau et al. (62). Similarly, in chickens, initial studies suggested GnIH could modulate the levels of $\mathrm{G \alpha}_{\mathrm{i} 2}$ mRNA in COS-7 cells transiently transfected with the GnIH-R, suggesting activation of $\mathrm{G \alpha}_{\mathrm{i}}(7)$. This was later confirmed in vitro as $\mathrm{GnIH}$ was shown to block forskolininduced cAMP accumulation in $\mathrm{GH}_{3}$ cells (a rat pituitary somatolactotrope line) transiently transfected with the chicken receptor (44). In addition, in this study, co-transfection of the chicken GnIH-R and gonadotropin-releasing hormone receptor III (GnRH-RIII) showed that activation of the GnIH-R resulted in the reduction of GnRH-induced cAMP response in a receptor ratiodependent manner, suggesting a direct interaction between the signaling of both GnIH-R and GnRH-RIII in chickens (44).

In fish, the intracellular signaling pathways used by GnIH-Rs have also been studied in vitro (for review: 63). Although, in tilapia, activation of the GnIH-R with LPXRFa-2 was shown to stimulate reporter constructs for both PKA and PKC suggesting coupling to $G \alpha_{s}$ and $G \alpha_{q}(56)$, stimulation of all three zebrafish GnIH-Rs (LPXRF-R1, LPXRF-R2 LPXRF-R3) transfected in COS7 cells failed to activate reporter constructs for PKC while LPXRFR2 and LPXRF-R3 exhibited a dose-response activation of reporter constructs for PKA, suggesting exclusive coupling to $G \alpha_{\mathrm{s}}$ (52). However, inhibition of cAMP accumulation was not measured in the above-mentioned studies. Further investigation in $\mathrm{CHO}$ cells demonstrated that both human NPFF-Rs (including GnIH-R or NPFF-R1) couple to $\mathrm{G \alpha}_{\mathrm{i} 3}$ and $\mathrm{G} \alpha_{\mathrm{s}}$ as the primary transducers, with NPFF-R2, additionally coupled to $G \alpha_{\mathrm{i} 2}$ and $G \alpha$ (64). This suggests that ligand binding could result in opposing signaling pathways and may in part explain the conflicting results outlined in Table 1. Interestingly, studies in mammals showed that although $\mathrm{GnIH}$ orthologues are the preferential ligand for 
TABLE 1 | List of GnlH-Rs orthologues across vertebrate species with localization and reported function.

\begin{tabular}{|c|c|c|c|c|c|c|c|c|}
\hline \multicolumn{9}{|c|}{ MAMMALS } \\
\hline \multirow[t]{2}{*}{ Species } & \multirow[t]{2}{*}{$\operatorname{Sex}^{1}$} & \multicolumn{2}{|r|}{ Receptor } & \multirow[t]{2}{*}{ Ligand } & \multicolumn{3}{|c|}{ Reported Function } & \multirow[t]{2}{*}{ References } \\
\hline & & Name & Localization $^{2}$ & & Reproductive & Metabolic & Other & \\
\hline $\begin{array}{l}\text { Horse } \\
\text { (Equus caballus) }\end{array}$ & $\mathrm{F}$ & NPFFR-1 & Hyp, Pit & RFRP-3 & No effect on $\mathrm{GnRH}$ or $\mathrm{LH}$ release & & & (22) \\
\hline \multirow{5}{*}{$\begin{array}{l}\text { Syrian hamster } \\
\text { (Mesocricetus } \\
\text { auratus) }\end{array}$} & M & GPR147 & $\begin{array}{l}\text { Hyp, BNST, } \\
\text { HbN, Hpc }\end{array}$ & RFRP-3 & Stimulates the HPG axis & $\begin{array}{l}\text { Potential role as an } \\
\text { intermediate between }\end{array}$ & & (23) \\
\hline & $\mathrm{F}$ & GPR147 & $\begin{array}{l}\text { Hyp, BNST, } \\
\text { HbN, Hpc }\end{array}$ & RFRP-3 & Inhibits LH release & $\begin{array}{l}\text { metabolic cues toward } \\
\text { central reproductive control }\end{array}$ & & \\
\hline & & GPR147 & $\begin{array}{l}\text { GnRH neurons, } \\
\text { Kiss neurons }\end{array}$ & RFRP-3 & $\begin{array}{l}\text { Inhibits gonadotropin release in } \\
\text { presence of } \mathrm{GnRH} \text { stimulation }\end{array}$ & & & $(24)$ \\
\hline & $\mathrm{F}$ & GPR147 & Pit & RFRP-3 & $\begin{array}{l}\text { Mediates LH surge at the level of } \\
\text { the Pit }\end{array}$ & & & (25) \\
\hline & M & GPR147 & $\mathrm{B}, \mathrm{T}$ & RFRP & Regulates spermatogenesis & & & (26) \\
\hline Siberian hamster & M & GPR147 & GnRH neurons & RFRP-1 & Inhibits LH release during LD; & & & $(27)$ \\
\hline $\begin{array}{l}\text { (Phodopus } \\
\text { sungorus) }\end{array}$ & & GPR147 & GnRH neurons & RFRP-3 & $\begin{array}{l}\text { promotes LH release during SD; } \\
\text { no effect on FSH }\end{array}$ & & & \\
\hline $\begin{array}{l}\text { Sheep } \\
\text { (Ovis aries) }\end{array}$ & & NPFFR-1 & $\begin{array}{l}\text { SCN, PeVN, } \\
\text { SON, PT }\end{array}$ & RFRP & $\begin{array}{l}\text { Potential role in photoperiodic time } \\
\text { measurement }\end{array}$ & & & (28) \\
\hline Human & & GPR147 & Adipose & NPFF & & Slow antilipolytic effect & & (29) \\
\hline \multirow[t]{4}{*}{ (Homo sapiens) } & & GPR147 & Adipose & NPSF & & Rapid antilipolytic effect & & \\
\hline & & GPR147 & Ov & RFRP-3 & Downregulates steroidogenesis & & & (30) \\
\hline & & GPR147 & Hyp, Pit & RFRP-3 & $\begin{array}{l}\text { Downregulates } \mathrm{GnRH} \text { expression; } \\
\text { directly inhibits gonadotropin } \\
\text { release }\end{array}$ & & & $(4)$ \\
\hline & & NPFFR-1 & $\begin{array}{l}\text { Hyp, Thal, Amyg, } \\
\mathrm{Cb}, \mathrm{Hpc}, \mathrm{SC}\end{array}$ & NPFF & & Potentially anorexigenic & $\begin{array}{l}\text { Pro- and anti- } \\
\text { opioid effects }\end{array}$ & (13) \\
\hline $\begin{array}{l}\text { Marmoset } \\
\text { (Callithrix jacchus) }\end{array}$ & & GPR147 & Hyp & RFRP & $\begin{array}{l}\text { Inhibits reproduction during the } \\
\text { prepubertal period }\end{array}$ & & & (31) \\
\hline \multirow[t]{3}{*}{$\begin{array}{l}\text { Pig } \\
\text { (Sus scrofa) }\end{array}$} & $\mathrm{F}$ & GPR147 & $\begin{array}{l}\text { Hyp, Pit, OB, } \\
\text { MO, Cb, Cbr, } \\
\text { Hpc, Ov, MO, } \\
\text { SC, spleen, } \\
\text { uterus, eye, } \\
\text { adrenal, kidney, } \\
\text { intestine }\end{array}$ & $\mathrm{GnlH}$ & $\begin{array}{l}\text { Regulates the estrus cycle in } \\
\text { sexually mature animals at all } \\
\text { levels of the HPG axis }\end{array}$ & & & (32) \\
\hline & $\mathrm{F}$ & GPR147 & Hyp, Pit, Ov & RFRP-3 & $\begin{array}{l}\text { Inhibits GnRH; downregulates } \\
\text { gonadotropin synthesis; } \\
\text { downregulates estradiol secretion }\end{array}$ & & & (33) \\
\hline & & NPFFR-1 & Hyp, Pit & RFRP-3 & $\begin{array}{l}\text { Suppresses LH pulses; regulates } \\
\text { sexual maturation }\end{array}$ & & & (34) \\
\hline $\begin{array}{l}\text { Cat } \\
\text { (Felis catus) }\end{array}$ & $\mathrm{F}$ & NPFFR-1 & Ov & RFRP-3 & $\begin{array}{l}\text { Increases progesterone } \\
\text { production from preantral follicles }\end{array}$ & & & (35) \\
\hline \multirow[t]{4}{*}{$\begin{array}{l}\text { Rat } \\
\text { (Rattus norvegicus) }\end{array}$} & & GPR147 & Hyp & RFRP & $\begin{array}{l}\text { Controls the prepubertal state and } \\
\text { reproductive development }\end{array}$ & & & (36) \\
\hline & & $\begin{array}{l}\text { NPFFR-1 } \\
\text { NPFFR-1 }\end{array}$ & $\begin{array}{l}\text { PVN, mPOA, } \\
\text { AHN, DMH, PMv, } \\
\text { LS, Thal, Amyg }\end{array}$ & $\begin{array}{l}\text { NPVF } \\
\text { NPAF }\end{array}$ & & & $\begin{array}{l}\text { Anti-opioid } \\
\text { effects }\end{array}$ & (16) \\
\hline & & NPFFR-1 & $\begin{array}{l}\text { Hyp, Pit, T, Ov, } \\
\text { Thal, Amyg, OB, } \\
\text { adrenal }\end{array}$ & NPFF & & Potentially anorexigenic & $\begin{array}{l}\text { Indirect role in } \\
\text { the } \\
\text { dopaminergic } \\
\text { system; pro- } \\
\text { and anti- } \\
\text { opioid effects }\end{array}$ & (13) \\
\hline & & $\begin{array}{l}\text { OT7T022 } \\
\text { OT7T022 }\end{array}$ & $\begin{array}{l}\text { Hyp, Pit, T, Ov, } \\
\text { Cbr, BG, Hpc, } \\
\text { Thal, Mes, Cb, } \\
\text { MO, SC, optic } \\
\text { nerve, eye, } \\
\text { adrenal, placenta }\end{array}$ & $\begin{array}{l}\text { RFRP-1 } \\
\text { RFRP-3 }\end{array}$ & Increases prolactin secretion & & & $(15)$ \\
\hline
\end{tabular}


TABLE 1 | Continued

\begin{tabular}{|c|c|c|c|c|c|c|c|c|}
\hline \multicolumn{9}{|c|}{ MAMMALS } \\
\hline \multirow[t]{2}{*}{ Species } & \multirow[t]{2}{*}{$\operatorname{Sex}^{1}$} & \multicolumn{2}{|r|}{ Receptor } & \multirow[t]{2}{*}{ Ligand } & \multicolumn{3}{|c|}{ Reported Function } & \multirow[t]{2}{*}{ References } \\
\hline & & Name & Localization $^{2}$ & & Reproductive & Metabolic & Other & \\
\hline & $M$ & NPFF1R & Amyg & RFRP-1 & & Anorexigenic & & $(37)$ \\
\hline & & GPR147 & $\begin{array}{l}\text { RP3V, Arc, MS, } \\
\text { POA, Pit, Hpc }\end{array}$ & RFRP-3 & $\begin{array}{l}\text { Regulates the central control of } \\
\text { reproduction in adults }\end{array}$ & & & (38) \\
\hline \multirow[t]{6}{*}{$\begin{array}{l}\text { Mouse } \\
\text { (Mus musculus) }\end{array}$} & $\mathrm{M}$ & NPFF1R & Hyp & RFRP-3 & & $\begin{array}{l}\text { Orexigenic action likely via } \\
\text { the modulation of the effects } \\
\text { of leptin and ghrelin on } \\
\text { feeding behavior; involved in } \\
\text { the regulation of glucose } \\
\text { homeostasis }\end{array}$ & & (39) \\
\hline & $\mathrm{F}$ & NPFF1R & Hyp & RFRP-3 & & $\begin{array}{l}\text { No effect on feeding } \\
\text { behavior; role in the } \\
\text { homeostatic control of body } \\
\text { weight and body } \\
\text { composition in basal } \\
\text { conditions; regulates energy } \\
\text { expenditure }\end{array}$ & & \\
\hline & & GPR147 & DS & RFRP-3 & Inhibits $\mathrm{GnRH}$ neurons & & & $(40)$ \\
\hline & & GPR147 & $\begin{array}{l}\text { GnRH neurons, } \\
\text { Kiss neurons, } \\
\text { PVN, LS }\end{array}$ & RFRP-3 & Inhibits Kiss and $\mathrm{GnRH}$ neurons & & & $(24)$ \\
\hline & & GPR147 & $\begin{array}{l}\text { GnRH neurons, } \\
\text { gonadotropes }\end{array}$ & $\mathrm{GnIH}$ & & & & $(41)$ \\
\hline & & GPR147 & Gonadotropes & $\begin{array}{l}\text { RFRP-1/ } \\
3\end{array}$ & $\begin{array}{l}\text { Downregulates gene expression of } \\
\mathrm{LH}-\beta \text {, FSH- } \beta \text {, and common } \alpha- \\
\text { subunits in presence of } \mathrm{GnRH} \\
\text { stimulation; inhibits LH release }\end{array}$ & & & $(42)$ \\
\hline
\end{tabular}

\section{AVES}

\begin{tabular}{|c|c|c|c|c|c|c|c|c|}
\hline Species & Sex & \multicolumn{2}{|c|}{ Receptor } & Ligand & \multicolumn{3}{|c|}{ Reported Function } & References \\
\hline $\begin{array}{l}\text { Japanese quail } \\
\text { (Coturnix japonica) }\end{array}$ & M & $\mathrm{Gn} \mid \mathrm{H}-\mathrm{R}$ & Pit, Cbr, Mes, SC & GnlH & $\begin{array}{l}\text { Inhibits gonadotropin release; } \\
\text { suppresses testosterone } \\
\text { production and testicular } \\
\text { development; negatively regulates } \\
\text { the development of secondary sex } \\
\text { characteristics }\end{array}$ & & & $(5,8)$ \\
\hline \multirow[t]{5}{*}{$\begin{array}{l}\text { Chicken } \\
\text { (Gallus gallus) }\end{array}$} & & $\begin{array}{l}\text { RFRPR } \\
\text { NPFFR }\end{array}$ & $\begin{array}{l}\text { Dien, Pit, Tel, OT, } \\
\text { OB } \\
\text { Dien, Pit, Ov, T, } \\
\text { Tel, OT, Cb, OB, } \\
\text { MO, SC, eye, } \\
\text { heart, liver, } \\
\text { adrenal, spleen }\end{array}$ & $\begin{array}{l}\text { GnIH } \\
\text { GnlH }\end{array}$ & Regulates gonadotropin release & & & (7) \\
\hline & & NPFFR-1 & Hyp & $\mathrm{GnlH}$ & & & & (43) \\
\hline & $\mathrm{F}$ & GnlH-R & Dien, Pit & GnlH & $\begin{array}{l}\text { Control of the prepubertal state; } \\
\text { regulates the termination of } \\
\text { reproduction }\end{array}$ & & & (44) \\
\hline & & $\mathrm{Gn} \mid \mathrm{H}-\mathrm{R}$ & Hyp & $\mathrm{GnlH}$ & & Orexigenic effects & & (45) \\
\hline & & GnIH-R & $\begin{array}{l}\mathrm{T}, \mathrm{Ov}, \\
\text { prehierachiral } \\
\text { follicles }\end{array}$ & GnlH & $\begin{array}{l}\text { Possibly downregulates gonadal } \\
\text { steroids; functions in follicular } \\
\text { selection and maturation }\end{array}$ & & & (46) \\
\hline
\end{tabular}


TABLE 1 | Continued

AVES

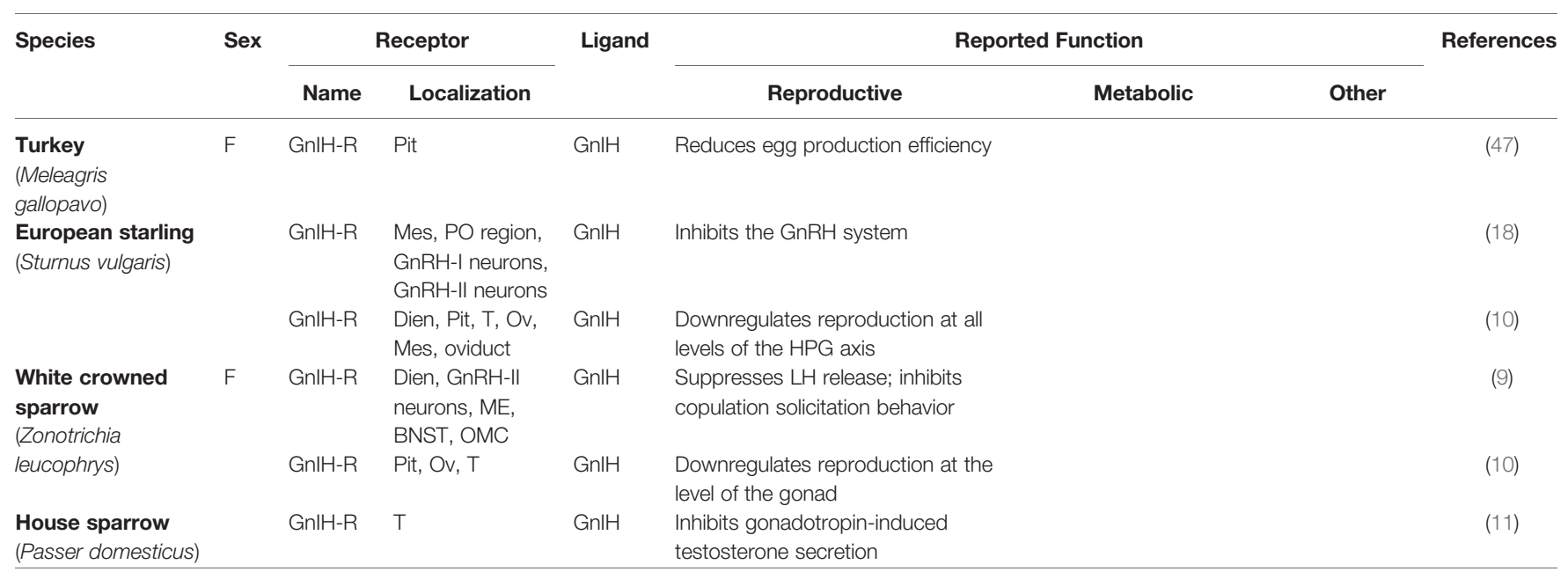

\section{TELEOSTS}

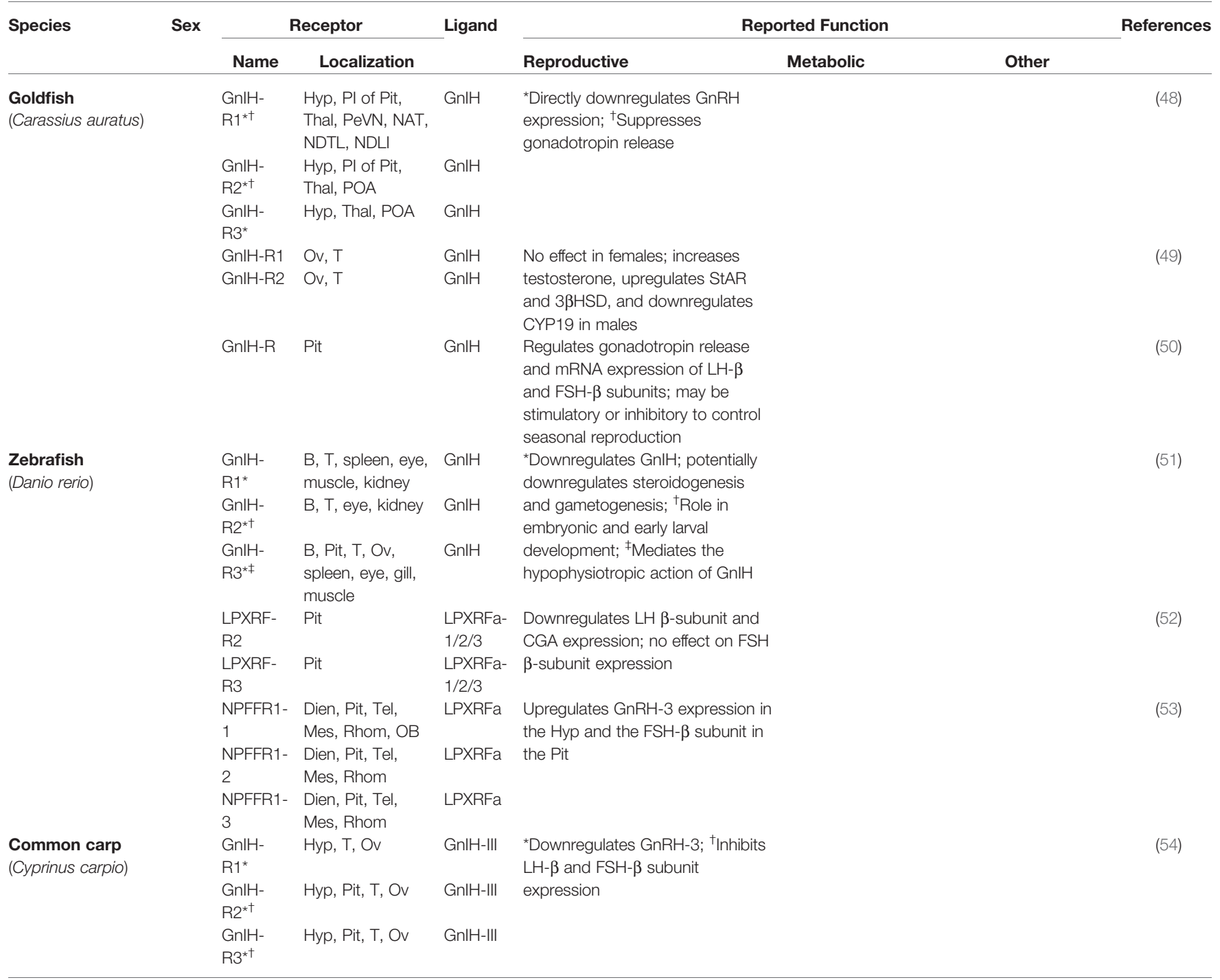


TABLE 1 | Continued

\begin{tabular}{|c|c|c|c|c|c|c|c|c|}
\hline \multicolumn{9}{|c|}{ TELEOSTS } \\
\hline \multirow[t]{2}{*}{ Species } & \multirow[t]{2}{*}{ Sex } & \multicolumn{2}{|r|}{ Receptor } & \multirow[t]{2}{*}{ Ligand } & \multicolumn{3}{|c|}{ Reported Function } & \multirow[t]{2}{*}{ References } \\
\hline & & Name & Localization & & Reproductive & Metabolic & Other & \\
\hline \multirow[t]{3}{*}{$\begin{array}{l}\text { Catla } \\
\text { (Catla catla) }\end{array}$} & & $\mathrm{GnlH}-\mathrm{R} 1$ & $\begin{array}{l}\text { B, G, kidney, } \\
\text { liver, heart, gill, } \\
\text { eye, stomach, } \\
\text { intestine }\end{array}$ & $\mathrm{GnIH}$ & $\begin{array}{l}\text { Primary site for } \mathrm{GnlH} \text { action in the } \\
\text { brain }\end{array}$ & & & $(55)$ \\
\hline & & GnlH-R2 & $\begin{array}{l}\text { B, G, kidney, } \\
\text { muscle, heart, } \\
\text { eye, stomach }\end{array}$ & $\mathrm{GnIH}$ & & & & \\
\hline & & $\mathrm{GnlH}-\mathrm{R} 3$ & $\begin{array}{l}\text { G, kidney, liver, } \\
\text { heart, gill, eye, } \\
\text { intestine }\end{array}$ & $\mathrm{GnlH}$ & & & & \\
\hline $\begin{array}{l}\text { Nile tilapia } \\
\text { (Oreochromis } \\
\text { niloticus) }\end{array}$ & $\mathrm{F}$ & LPXRF-R & $\begin{array}{l}\text { Dien, Pit, T, Ov, } \\
\text { Tel, Mes, liver, } \\
\text { intestine, } \\
\text { adipose, muscle, } \\
\text { gill, heart, } \\
\text { stomach }\end{array}$ & LPXRFa & Upregulates LH and FSH & & & $(56)$ \\
\hline $\begin{array}{l}\text { Orange-spotted } \\
\text { grouper } \\
\text { (Epinephelus } \\
\text { coioides) }\end{array}$ & $\mathrm{H}$ & GnlH-R & $\begin{array}{l}\text { Hyp, Pit, G, OB, } \\
\text { Tel, OT, Cb, MO, } \\
\text { gill, kidney, } \\
\text { stomach }\end{array}$ & $\begin{array}{l}\text { GnIH-I/II/ } \\
\text { III }\end{array}$ & $\begin{array}{l}\text { Decreases } \mathrm{GnRH} \text { in brain and } \\
\text { suppresses } \mathrm{LH} \text { release }\end{array}$ & & & (19) \\
\hline $\begin{array}{l}\text { Clownfish } \\
\text { (Amphiprion }\end{array}$ & $\mathrm{H}$ & GnlH-R & B, Pit, G, eye & $\mathrm{GnIH}$ & $\begin{array}{l}\text { Downregulates gonadotropins; } \\
\text { potential role in sex change }\end{array}$ & & & $(57)$ \\
\hline melanopus) & & GnlH-R & Dien & $\mathrm{GnlH}$ & $\begin{array}{l}\text { Downregulates } \mathrm{GnRH} \text { expression } \\
\text { and suppresses } \mathrm{LH} \text { and FSH } \\
\text { synthesis and release }\end{array}$ & & & $(58)$ \\
\hline $\begin{array}{l}\text { Grass puffer } \\
\text { (Takifugu niphobles) }\end{array}$ & & $\begin{array}{l}\text { LPXRFa- } \\
\text { R }\end{array}$ & $\begin{array}{l}\text { Dien, Pit, Tel, OT, } \\
\text { eye }\end{array}$ & LPXRFa & $\begin{array}{l}\text { Upregulates LH- } \beta \text { and FSH- } \beta \\
\text { subunit expression }\end{array}$ & & & (59) \\
\hline \multirow[t]{2}{*}{$\begin{array}{l}\text { Tongue sole } \\
\text { (Cynoglossus } \\
\text { semilaevis) }\end{array}$} & & $\begin{array}{l}\text { LPXRFa- } \\
\mathrm{R}\end{array}$ & $\begin{array}{l}\text { B, Pit, Ov, gill, } \\
\text { heart, liver, } \\
\text { spleen, kidney, } \\
\text { stomach, } \\
\text { intestine, muscle }\end{array}$ & $\begin{array}{l}\text { LPXRAa- } \\
1\end{array}$ & Stimulatory action & & & $(60)$ \\
\hline & & $\begin{array}{l}\text { LPXRFa- } \\
\text { R }\end{array}$ & $\begin{array}{l}\text { B, Pit, Ov, gill, } \\
\text { heart, liver, } \\
\text { spleen, kidney, } \\
\text { stomach, } \\
\text { intestine, muscle }\end{array}$ & $\begin{array}{l}\text { LPXRAa- } \\
2\end{array}$ & Inhibitory action & & & \\
\hline
\end{tabular}

${ }^{1}$ Sex abbreviations: M, Male; F, Female; H, Hermaphrodite.

2Localization abbreviations: Amyg, Amygdala; AHN, Anterior hypothalamic nucleus; Arc, Arcuate nucleus; BG, Basal ganglia; BNST, Bed nucleus of the stria terminalis; B, Brain; Cb, Cerebellum; Cbr, Cerebrum; Dien, Diencephalon; DS, Dorsal septal nucleus; DMH, Dorsomedial hypothalamus; G, Gonad; HbN, Habenular nuclei; Hpc, Hippocampus; Hyp, Hypothalamus; LS, Lateral septum; mPOA, Medial preoptic nucleus; MS, Medial septum; ME, Median eminence; MO, Medulla oblongata; Mes, Mesencephalon; NAT, Nucleus anterior tuberis; NDLI, Nucleus diffuses lobi inferioris; NDLT, Nucleus diffuses tori lateralis; BNST, Nucleus stria terminalis; OMC, Oculomotor complex; OB, Olfactory bulb; OT, Optic tectum; OV, Ovary; PVN, Paraventricular nucleus; PI, Pars intermedia; PT, Pars tuberalis; PeVN, Periventricular nucleus; Pit, Pituitary; POA, Preoptic area; Rhom, Rhombencephalon; RP3V, Rostral periventricular area of the third ventricle; SC, Spinal cord; SCN, Suprachiasmatic nucleus; SON, Supraoptic nucleus; Tel, Telencephalon; T, Testis; Thal, Thalamus; VMH, Ventromedial hypothalamus.

GnIH-R, other members of the RFamide family can also bind and activate it. For example, the human GnIH-R was shown to also bind several other endogenous peptides possessing an FLFQPQRFa sequence, although with lower affinity (62). In fact, cross-activation of receptors by multiple members of the RFamide family commonly occurs, as demonstrated by kisspeptin-10 and kisspeptin-54 shown to bind and activate both NPFF receptors, including the GnIH-R. In any case, this resulted in increased $\mathrm{Ca}^{2+}$ mobilization and decreased cAMP accumulation, confirming the coupling of mammalian $\mathrm{GnIH}-\mathrm{Rs}$ to both $\mathrm{G} \alpha_{\mathrm{q} / 11}$ and $\mathrm{G \alpha}_{\mathrm{i} / \mathrm{o}}$ (65).

Interestingly, in the case of kisspeptin, the cross-activation appears to be unidirectional, as $\mathrm{GnIH}$ orthologues failed to significantly bind to and activate GPR54, the known receptor to kisspeptin (65). As RFamides and their receptors have significant clinical implications in humans, specific agonists and antagonists have been designed over the years. However, as for their native ligand, specificity may be an issue due to the promiscuity of NPFF-Rs (for review: 17). As a matter of fact, known agonists of GPR54 were shown to also bind to the GnIH$\mathrm{R}$ and elicit intracellular $\mathrm{Ca}^{2+}$ mobilization, although they failed to mediate a decrease in cAMP accumulation (65). This suggests that while mammalian GnIH-Rs can couple to both $\mathrm{G} \alpha_{\mathrm{q} / 11}$ and $\mathrm{Go}_{\mathrm{i} / \mathrm{o}}$, the activation of downstream signaling is dependent on the ligand. In fact, this lack of receptor subtype selectivity can be 
a significant challenge for the development of therapeutics, as recently discussed by Nguyen et al. (66).

Nonetheless, beyond therapeutic applications, the promiscuity of ligands for NPFF-Rs have significantly widened the physiological relevance of RF-amide peptides, including $\mathrm{GnIH}$. For example, NPFF has a strong affinity for the GnIH-R (13), suggesting that the physiological impacts of GnIH-R activation depend on receptor localization and ligand availability. In mammals, particular attention has been placed on the role of NPFF and its receptors on modulating nociception, especially as it relates to opioid-induced analgesia $(67,68)$. Interestingly, the distribution of GnIH-R (NPFF-R1) and NPFF-R2 within the central nervous system differs amongst mammalian species (13), further highlighting the importance of both the presence of receptors and ligand availability. Nonetheless, the presence of GnIH-Rs throughout the hypothalamus suggests involvement in multiple neuroendocrine processes, and while $\mathrm{GnIH}$ was first identified as an inhibitory hypothalamic peptide on reproduction (1), it has since been shown to also participate in behavior, stress, and metabolism (for review: 3 ), all associated with energy balance and nutrient partitioning.

\section{GnIH AND ITS RECEPTOR IN THE BRAIN, INVOLVEMENT IN MULTIPLE NEUROENDOCRINE SYSTEMS}

Since its discovery, GnIH has been localized throughout the brain of many species, especially the diencephalon and mesencephalon, with particular emphasis on the hypothalamic region $(4,27,69,70)$. Despite some variations among species, $\mathrm{GnIH}$ perikarya have been located in the paraventricular nucleus (PVN) of quail $(71,72)$ and many other wild bird species $(18,73-$ $75)$, the dorsomedial hypothalamic area (DMH) in hamsters and mice $(14,27)$, the periventricular nucleus (PerVN) in rats (15), and the dorsomedial nucleus, as well as the PVN in sheep (76). Neuronal projections have also been identified extending throughout the brain, including the preoptic area (POA), lateral septum, arcuate nucleus (ARC), and anterior hypothalamus in mammals $(14,70,77,78)$. Similar to the expression patterns of $\mathrm{GnIH}, \mathrm{GnIH}-\mathrm{R}$ is expressed throughout the hypothalamus, specifically in the POA, rostral periventricular area of the third ventricle (RP3V) and ARC. With further expression in the pituitary gland (38), this widespread localization within the hypothalamic area strongly suggests multiple neuroendocrine functions. However, the expression of $\mathrm{GnIH}$ and its receptor in the ARC is of particular interest, as this area is involved in the regulation of both reproduction and energy homeostasis (reviewed by: 79), which is further discussed below.

\section{Neuroendocrine Control of Reproduction Seasonal Breeders}

Long Day (LD) Breeders

Species such as chickens, deer, horses, and fish such as salmon, carp, seabass, tilapia, goldfish, and grass puffer (50, 59, 80-90), are diurnal seasonal breeders known to be reproductively active under long day lengths. Since the first species in which $\mathrm{GnIH}$ was identified was the quail (1), most of the early research on the effect of $\mathrm{GnIH}$ on reproduction involved avian species and the relationship with photoperiodicity. Specifically, an increase in melatonin released by the pineal gland and retina of the eye during the dark period results in an elevation of GnIH synthesis and release from the hypothalamus (86). In turn, binding of $\mathrm{GnIH}$ to its receptor on GnRH-containing neurons inhibits $\mathrm{GnRH}$ synthesis and release, while binding to its receptor in the anterior pituitary directly inhibits the production of gonadotropins (5). This inhibition of LH secretion was further confirmed in several other avian species, including chickens, white-crowned sparrows, and quail $(5,73,91)$. As in avian species, the photoperiodic control of reproduction in many fish species is regulated by melatonin released from the retina of the eye and the pineal gland (Review by: 88), suggesting a common mechanism involving $\mathrm{GnIH}$. As a matter of fact, administration of GnIH-3 downregulates $\mathrm{GnRH}$ and $\mathrm{LH} \beta$ mRNA levels in goldfish (48), clownfish (57), zebrafish (52), and sole fish (92). Additionally, GnIH-3 administration decreases the expression of GnRH-I in the orange-spotted grouper (19), while in the common carp, expression of both $\mathrm{LH} \beta$ and $\mathrm{FSH} \beta$ are downregulated (54). Conversely, in the sockeye salmon, in vitro stimulation of pituitary cells with all three $\mathrm{GnIH}$ orthologs induced an elevation in FSH and $\mathrm{LH}$ release (93), while in vitro treatment of grasspuffer fish pituitary cells with goldfish GnIH resulted in an elevation in $\mathrm{FSH} \beta$ and $\mathrm{LH} \beta$ subunit mRNA levels (59). Interestingly, the inhibitory effects of $\mathrm{GnIH}$ on gonadotropins were observed upon in vivo treatment, while the stimulatory effects were obtained in vitro using primary pituitary cell cultures and would need to be further confirmed in vivo.

In avian species, upon photostimulation, decreasing levels of melatonin result in a decrease in GnIH synthesis, thus lifting the inhibition on the hypothalamic-pituitary-gonadal (HPG) axis and allowing for the release of $\mathrm{GnRH}$ and the subsequent activation of pituitary gonadotropes $(94,95)$. Interestingly, in chickens, once the axis has been activated, ovarian production of estradiol downregulates the expression of the GnIH-R in the pituitary gland (46), thus switching the sensitivity of the adenohypophysis in favor of stimulatory inputs $(44,94)$.

In nocturnal species, such as hamsters, studies on the role of $\mathrm{GnIH}$ frequently resulted in conflicting results, with both stimulatory and inhibitory effects reported $(96,97)$. This is possibly due to the contrasting role of melatonin in these species, with elevated levels during the dark phase contributing to heightened activity. In fact, central administration of $\mathrm{GnIH}$ stimulated the HPG axis of Syrian and Siberian male hamsters exposed to short day (SD) lengths, with $\mathrm{GnIH}$ triggering the release of $\mathrm{LH}(27,98)$. However, when male Siberian hamsters were exposed to long day (LD) lengths, GnIH administration led to an inhibition of LH release (27). Additionally, gonadotropin production was suppressed in female Syrian hamster following intracerebroventricular (ICV) injection of $\mathrm{GnIH}$, with no day length effect reported in this study (14). Therefore, additional 
sex-specific differences may be at play in this species as GnIH-R mRNA levels were reported to be higher in females than males across all tissues examined (23). However, GnIH-R mRNA levels were consistently elevated in hamsters maintained under LD versus SD, regardless of sex (23), suggesting differential regulation of $\mathrm{GnIH}$ and $\mathrm{GnIH}-\mathrm{R}$ by melatonin and/or photoperiod compared to diurnal breeders. Nonetheless, in the same study, GnIH fibres were found to be more abundant in females under SD than LD, while no changes were observed in males (23). Interestingly, in ovariectomized Syrian hamsters, it has been suggested that time of day is critical in the determination of the sensitivity of the HPG axis to GnIH administration, with GnIH-R and LH $\beta$ mRNA levels exclusively downregulated when ICV injection occurred in the afternoon, while morning administration had no effect (97). This is consistent with the established model of diurnal, seasonal breeders and the timing of the LH surge as GnIH-ir cells significantly declined at the time of the surge in Syrian hamsters (25).

\section{Short Day (SD) Breeders}

In the case of short-day seasonal breeders such as the rhesus monkey, elevated melatonin levels lead to the advancement of puberty and the presentation of sexual cues (99). In this species, GnIH mRNA levels were upregulated in the pre-pubertal phase, and due to the association with GnRH during this period, it has been suggested that the inhibitory activity of GnIH contributes to the pulsatility and reduced firing rate of $\mathrm{GnRH}$ neurons, maintaining reproduction in an inactive state $(31,100)$. Furthermore, GnIH and its receptor were observed to be highest in adults (31). In sheep, GnIH treatment has also been shown to reduce the synthesis and release of gonadotropins (76, 101), and more recently, the use of a GnIH-R antagonist, RF9, resulted in the stimulation of gonadotropin production in ewes (102). However, upon further investigation, RF9 was not only found to be nonspecific to NPFF-R1 (GnIH-R) and NPFF-R2, but also acted as an agonist of GPR54, which could have resulted in the stimulation of LH release (103). To overcome the lack of specificity, additional antagonists were developed, with RF313 and GJ14 displaying moderate to high specificity for the GnIH-R with no impact on GPR54 $(103,104)$. In fact, while GJ14 does not impact forskolin-induced cAMP production, it was shown to block all effects of $\mathrm{GnIH}$ (103), making this receptor antagonist a valuable tool for future studies.

\section{Non-Seasonal Breeders}

Non-seasonal breeders include spontaneous ovulating species, such as humans, rats, mice, and naked mole rats, as well as induced ovulating species, such as the domestic cat. Unlike short-day and long-day breeders, the literature on nonseasonal breeders is more consistent, and $\mathrm{GnIH}$ and its receptor were shown to be present in all three levels of the HPG axis $(13,15,30,35,105)$. Interestingly, puberty in humans has been hypothesized to be better anticipated by measuring the accumulation of fat rather than using age or environmental stimuli as a predictor (106). Therefore, it is not surprising that a direct role of $\mathrm{GnIH}$ on the hypothalamic control of reproduction appears to be substantially less critical than in seasonal breeders, as demonstrated by the reduced number of projections of $\mathrm{GnIH}$ neurons to $\mathrm{GnRH}$ neurons in the mouse (14) and GnIH projections to the median eminence (ME) in the rat and mouse $(70,77,107)$. However, IV administration of $\mathrm{GnIH}$ still resulted in an inhibition of the GnRH-induced $\mathrm{LH}$ production in ovariectomized rats $(107,108)$. Although a decline in the expression of both GnIH and GnIH-R were reported around sexual maturation in male rats, while in females, the expression of $\mathrm{GnIH}$ increased and the expression of GnIH-R significantly declined between 28 and 49 days of age (36), again indicating a possible sex-related difference in the regulation of and sensitivity to GnIH. In naked mole rats, only dominant females can undergo spontaneous ovulation and breeding females display elevated numbers of kisspeptin cells while nonbreeders presented an elevated number of GnIH cells (105). Beyond puberty and ovulation, GnIH levels in rats significantly declined immediately following parturition (109), likely playing a role in facilitating postpartum estrus in this species $(110,111)$. Thus, although the role of GnIH may be more discrete in nonseasonal breeders, the inhibitory impact on reproduction is still conserved.

\section{Interaction With Kisspeptin and Its Receptor}

Since its initial discovery as a novel gene in humans (112), kisspeptin, along with its receptor (GPR54/Kiss-1r; 113), was shown to control puberty and reproduction in mammals via direct stimulation of GnRH neurons (114-119). In fact, along with neurokinin B and dynorphin, kisspeptin is part of an intricate neuronal circuitry responsible for the pulsatile secretion of GnRH, referred to as the KNDy neurons (for review: 120). Interestingly, GnIH-Rs are expressed in 9-16\% of RP3V kisspeptin neurons in rats (24), as well as in $5-10 \%$ of the anteroventral periventricular nucleus (AVPV) and 25\% of ARC Kiss1 neurons in mice (121). Additionally, Kiss1 neurons in the ARC are in close proximity to GnIH fibres (121), suggesting that GnIH may directly inhibit a subset of kisspeptin neurons and thus inhibit reproduction (122), although a reciprocal effect was not identified (121). In mice, GnIH-R knockout (KO) resulted in a weaker disruption of LH secretion (123) compared to GPR54 KO (124). However, Kiss 1 mRNA was found to increase in GnIH-R KO mice (123), and with 33\% of GnRH neurons also expressing GnIH-R in rats, GnIH likely acts at multiple levels (GnRH and kisspeptin neurons) to inhibit GnRH synthesis and release (24). This is further supported by the similarities in expression patterns between GnIH-R and GPR54 as previously reported $(15,125)$.

In long-day breeders, shorter day lengths result in increased expression of $\mathrm{GnIH}$ due to higher melatonin (86), while the number of kisspeptin-positive cells in the ARC and Kiss 1 mRNA levels decline (126-129). Interestingly, when hamsters maintained under a short-day length were treated with Kp10, maturation of the reproductive tract was observed, with organ weights comparable to that under long days (96), indicating that exogenous kisspeptin is able to override the need for photostimulation. As discussed further in the following sections, beyond photoperiod, switching the activity of the HPG axis from inhibitory to stimulatory may intimately be 
linked to metabolic status and the hypothalamic control of energy reserves and nutrient partitioning (130, 131). This is further supported as a relationship between kisspeptin, photoperiod, and food availability has previously been established in seasonal mammals (132).

Furthermore, as avian species require a significant shift in energy partitioning towards egg production, metabolic status may be the primary cue controlling the activation of the HPG axis (133). Thus, the absence of a Kp gene in several avian species $(134,135)$ may allow $\mathrm{GnIH}$ to take a central role in balancing energy status and reproduction.

\section{Integration With the Central Regulation of Metabolic Processes \\ Regulation of Body Weight and Composition}

The relationship between reproduction and body weight has been previously described in mammalian and avian species $(133,136-$ 139), with a minimum body weight threshold required to initiate the activation of the HPG axis $(140,141)$. Prior to sexual maturation, animals undergo a rapid weight gain and growth phase while the HPG axis remains suppressed, possibly via elevated levels of GnIH. For example, moderate to high intraperitoneal doses of $\mathrm{GnIH}$ in mice were reported to evoke an increase in body mass (142), and chronic GnIH ICV injection elevated both body weight and feed intake in male mice (143). Initially, it was proposed that body weight was under the dual control of both $\mathrm{GnIH}$ and its stimulatory counterpart, as $\mathrm{GnRH}$ agonist treatment also resulted in a dose-dependent body mass gain in rats (144). However, the impact GnRH had on body weight was likely the outcome of a $\mathrm{GnRH}$-stimulated increase in the expression of neuropeptide Y (NPY), as this peptide not only stimulates feed intake but has additionally been implicated in the preovulatory surge $(145,146)$. Furthermore, as described in the following section, more recent evidence suggests that beyond the central nervous system, GnIH can also influence body weight via direct control of adiposity in male mice, acting independently of reproductive steroids or the melanocortin system (96).

In view of the promiscuity between ligand and receptors from the RFamide peptide family, it is reasonable to question whether the impact of $\mathrm{GnIH}$ on body weight is mediated through its own receptor. This could partly be answered using GnIH-R KO, and in mice, inactivation of the GnIH-R resulted in significantly heavier females, yet it did not impact the weight of males (39), suggesting that the impact of $\mathrm{GnIH}$ on body weight is sexdependent and most likely related to reproduction. Since in mammals, the GnIH-R was shown to couple to both $\mathrm{G \alpha}_{\mathrm{i} 3}$ and $G \alpha_{s}(64)$, the observed differences between males and females may point to a differential receptor activation and signalling between sexes (147). In fact, when GnIH-KO and control mice were fed high-fat diets (HFD) and low-fat diets (LFD), males displayed declined locomotor activity in both KO groups, while female mice in both $\mathrm{KO}$ groups demonstrated elevated fat mass over the control (39). However, regardless of sex, obese (ob/ob) mice displayed lower GnIH mRNA levels in the dorsal-medial nucleus than their wild-type counterparts (148). Taken together, these studies suggest that as proposed by Cázarez-Márquez et al.
(96), the impact of $\mathrm{GnIH}$ and its receptor on body weight may be linked to adiposity, which is also intimately associated with reproduction. Back in 1974, Frisch and McArthur (106) postulated the 'critical weight hypothesis,' which states that the accumulation of body fat stores may be a better indicator of the timing of sexual maturation rather than age or body weight itself. This has further been confirmed in rats, as well as chickens, with insufficient fat stores resulting in pubertal delay $(136,149,150)$ and diet-induced obesity resulting in declined reproductive capacity $(151,152)$. In a recent study, GnIH injections resulted in the elevation of serum total triglycerides and cholesterol (153), leading to increased uptake of triglycerides by the adipose tissue (142). Thus, it could be hypothesized that GnIH acts to control fat deposition in adipose tissue not only in immature animals but also in adults. This is partially supported by the association between $\mathrm{GnIH}$-induced increased body weight and increased brown adipose tissue (BAT) mass and liver mass (143). However, although $\mathrm{GnIH}$ appears to stimulate fat deposition, male $\mathrm{GnIH}$ $\mathrm{R}$ KO mice were not protected from body weight gain on a highfat diet (39), and a lack of GnIH-R signalling did not prevent obesity. Additionally, with GnIH-stimulated feed intake reported to trigger dyslipidemia (153) and abnormal glucose metabolism $(143,154), \mathrm{GnIH}$ may play a larger peripheral role in the control of metabolism than previously thought (discussed in a following section).

\section{Regulation of Feed Intake via the Melanocortin System}

It is well-established that the melanocortin system controls feed intake through the orexigenic peptides, neuropeptide Y (NPY) and agouti-related peptide (AgRP), and the anorexigenic peptides, pro-opiomelanocortin (POMC) and cocaine-andamphetamine regulated transcript (CART) (155-160). Neurons from the melanocortin system have been localized throughout many regions of the hypothalamus $(24,161)$ and shown to be in close contact with $\mathrm{GnIH}$ neurons in the $\mathrm{DMH}$, with $\mathrm{GnIH}$ containing fibres projecting to the ARC and PVN in mice (77, 162). In fact, the orexigenic effect of GnIH is mediated through the modulation of POMC and NPY neuronal activity $(24,161$, $163,164)$, with POMC downregulated in the presence of $\mathrm{GnIH}$ $(161,164,165)$. In GnIH-R KO male mice, POMC mRNA levels in the hypothalamus are elevated compared to wild type (39), further suggesting a direct role for $\mathrm{GnIH}$ and its receptor in the inhibition of the anorexigenic response. However, the direct role of GnIH on NPY appears to be more ambiguous $(161,164)$. In mice, $\mathrm{GnIH}$ has been reported to inhibit the neuronal activation of NPY (161), yet in chicks, sheep, and rats, GnIH was shown to stimulate NPY, prompting an increase in feed intake $(165,166)$. Nonetheless, whether acting on both branches of the melanocortin system or not, ICV administration of $\mathrm{GnIH}$ increases feeding duration (167) and overall feed intake in chickens and rats $(70,108,165,168)$. However, the injection of $\mathrm{GnIH}$ into the amygdala of rats also resulted in an opposite effect with the suppression of food intake (37). Interestingly, despite mediating increases in feed intake in sheep, $\mathrm{GnIH}$ administration did not result in a reduction in energy expenditure, as measured 
by calorimetry (166). This strongly suggests that the effect of $\mathrm{GnIH}$ on feed intake is not intended to achieve or restore energy homeostasis but may rather coordinate the partitioning of energy away from reproduction (169). However, chronic ICV injection of $\mathrm{GnIH}$ in mice did decrease energy expenditure and increased feed intake, contributing to a rapid decline in brown adipose tissues (BAT) activity prior to an accumulation in lipid droplets, thus elevating BAT deposition overall (143). This effect also resulted in a $\mathrm{GnIH}$-induced decrease in core body temperature during short exposure to the dark phase, suggesting for the first time that $\mathrm{GnIH}$ contributes to the conservation of energy (143).

In songbirds and zebra finches, food deprivation results in a decline in the number of GnIH-ir cells (170), although no differences in mRNA or peptide were observed $(171,172)$. As hypothesized by Fraley et al. (167), this decrease in GnIH-ir cells following feed restriction is likely the result of chronic metabolic stress. Of interest, declining $\mathrm{GnIH}$-ir cell numbers have been correlated to declining body mass in female songbirds (170). When GnIH-R deficient male mice underwent 12-h fasting, despite a large decline in body mass, no change in $\mathrm{LH}$ secretion was detected. Conversely, in their wild-type counterparts, an immediate decline in LH secretion occurred following a 12-h fasting (123). Taken together, these studies provide an alternative pathway by which $\mathrm{GnIH}$ is able to mediate feed-seeking behavior via body mass fluctuations (170).

Since the leptin receptor is co-expressed with NPY and POMC, leptin is also thought to regulate feed intake (173, 174). Thus, a possible integration between $\mathrm{GnIH}$ and leptin has been investigated. This led to the identification of the long form of the leptin receptor (LepRb), present on 15 to $20 \%$ of GnIH neurons (148). This finding highlights a possible pathway between $\mathrm{GnIH}$ and the regulation of adiposity via leptin and feed intake (175). With diminished levels of GnIH observed in the leptin-deficient ob/ob mice, a direct inhibition from leptin via the small subset of LepRb-expressing neurons is possible, yet alternative indirect hypotheses have also been proposed (148). However, leptin acts through the PKC-dependent pathway to promote intracellular $\mathrm{Ca}^{2+}$ signalling within $\mathrm{GnIH}$ neurons, thereby potentially eliciting an indirect effect on appetite control and an indirect negative feedback to $\mathrm{GnRH}$ neurons (176), which lack the LepRb (177). Thus, elevated circulating leptin results in a decline in GnIH activity (178), leading to low LH levels in ob/ob mice, resulting in infertility (179). However, reactivation of the HPG axis is possible with leptin treatment (180, 181), illustrating a possible multipronged link between metabolism and reproductive success $(182,183)$, with leptin additionally proposed as a regulator in the timing of puberty (184). Furthermore, as both leptin and GnIH activate the PI3K/ Akt signalling pathway (185, 186), Anjum et al. (175) hypothesized that PI3K/Akt signalling in ventromedial nucleus of the hypothalamus (VHM) neurons is responsible for the coordination of energy homeostasis (further discussed in a following section).

\section{GnIH and Central Ghrelin}

In addition to the melanocortin system, ghrelin, a hormone traditionally referred to as the 'hunger hormone,' is also involved in the control of appetite. As for $\mathrm{GnIH}$, ghrelin elicits a stimulatory effect on food intake and an inhibitory effect on gonadotropin secretion through the growth hormone secretagogue receptor (GHS-R) (187) present on GnRH neurons (188). While this hormone has been primarily linked to the gastrointestinal tract, it was also identified in the brain of chickens (189), mice, and rats (190, 191), pointing to a neuroendocrine role beyond the gut. Specifically, ghrelincontaining hypothalamic neurons have been proposed to interact with NPY and AgRP-containing neurons to stimulate the secretion of orexigenic peptides in rodents $(190,191)$. Beyond appetite control, ghrelin can also inhibit LH (192), and testosterone production through the inhibition of steroidogenic enzymes (193), contributing to the suppression of the HPG axis during periods of insufficient energy stores (reviewed by: 194). Interestingly, when fed a HFD, GnIH-R KO mice demonstrated a complete resistance to the central administration of ghrelin, failing to prompt an increased cumulative feed intake compared to their wild-type counterparts (39). This suggests that the effect of ghrelin on appetite control may be in part mediated via GnIH and its receptor. However, the suppression of ghrelin effects in $\mathrm{GnIH}-\mathrm{R} \mathrm{KO}$ was not sustained when mice were fed a LFD (39). Since it has previously been reported that rats fed a HFD do not display ghrelin-induced hyperphagia but do maintain the increased adiposity also observed in LFD-fed rats, ghrelin may utilize separate mechanisms to act on appetite and lipid metabolism (195). In fact, Anjum et al. (175) suggested that the ghrelin receptor involved in the brain may be different and not yet identified.

\section{Integration With the Stress Response}

The relationship between the hypothalamo-pituitary-adrenal (HPA) axis and GnIH has been previously established (Reviewed by: 196). GnIH neurons in the PVN are in direct contact with neurons containing corticotrophin releasing hormone $(\mathrm{CRH})$; (163), which upon release, triggers the activation of the stress axis $(197,198)$. Furthermore, the CRH receptor 1 is expressed in $13 \%$ of $\mathrm{GnIH}$ neurons and its activation has been shown to elevate GnIH-R mRNA in vitro (199). As well, GnIH neurons have been shown to respond to mediators of acute and chronic stress (199-201). These stressors include but are not limited to, immunological stress, physical restraint, and social isolation and defeat. Specifically, a lipopolysaccharide (LPS) challenge in female rats resulted in a significant elevation in GnIH and GnIH-R expression, concurrent with a direct downregulation in LH- $\beta$ mRNA (202). A similar inhibitory effect on the HPG axis was observed during social defeat stress in tilapia, with pituitary GnIH-R levels significantly increasing along with cortisol levels $(203,204)$. This was further validated in immobilized Wistar rodents (199), although in socially isolated male Sprague-Dawley rats, both GnRH mRNA expression and $\mathrm{GnIH}$ neuronal activity were suppressed, while no changes in the number of $\mathrm{GnIH}$ cells were detected (205). Taken together, experimental evidence suggests that $\mathrm{CRH}$ can directly activate a proportion of hypothalamic $\mathrm{GnIH}$ neurons and increase $\mathrm{GnIH}$ sensitivity by upregulating the GnIH-R. As for most neuroendocrine responses, 
chronic activation of the $\mathrm{CRH}$ receptor can lead to the desensitization of the HPA axis (206). Thus, it has been hypothesized that $\mathrm{CRH}$ sensitive $\mathrm{GnIH}$ cells may also become unresponsive, resulting in the interruption of the GnIH-GnRH neuronal pathway during sustained chronic stress (205). Since the GnIH-R is also expressed in pituitary corticotropes along with POMC, the precursor peptide of ACTH (207), the interactions between $\mathrm{GnIH}$ and the HPA axis appears bidirectional and in fact, ICV injection of GnIH in tilapia led to an elevation in plasma ACTH levels (208). However, recent studies have demonstrated that this is unlikely due to co-expression of GnIH-R and POMC, as pituitary expression of GnIH-R was elevated during social defeat, along with an elevation in GnIH mRNA and cell numbers, while POMC remained unaffected (204).

As discussed in the previous section, GnIH is implicated in metabolic control via feed intake and energy partitioning. In birds, metabolic stress can be induced by feed deprivation, resulting in serum corticosterone levels 13 times higher than under ad libitum feeding, although no change in the number of $\mathrm{CRH}$-ir neurons were observed in the PVN (170). A positive correlation between serum corticosterone levels and mass loss was previously identified (170). However, whether the loss of mass was directly induced by corticosterone, or the consequence of reduced feed intake, is not clear and could potentially involve GnIH. Of interest, glucocorticoid receptors (GRs) are present in GnIH cells (201), and activation of GR via the administration of synthetic glucocorticoids such as dexamethasone stimulates GnIH and GnIH-R transcription (209). Interestingly, although chronic administration of corticosterone resulted in the stimulation of $\mathrm{GnIH}$ synthesis in the diencephalon of quail, acute injections did not (201), suggesting that the impact of stress on reproduction via $\mathrm{GnIH}$ is intended to adapt to longer-term impact. Furthermore, since $\mathrm{GnIH}$ is more effective at interrupting reproduction during the early breeding season in rock doves (210), the impact of stress on GnIH may allow the delay of sexual maturation when conditions, such as food availability, are not favourable.

\section{Integration With the Central Control of Thyroid Hormones}

Similar to GnIH, THs have been implicated in both reproduction and metabolism. Since THs upregulate the basal metabolic rate of most cells of the body, hypothyroidism is associated with significant increases in body weight, along with high levels of TSH due to the absence of negative feedback $(211,212)$. Conversely, systemic or central (ICV) administration of $\mathrm{T}_{3}$ results in weight loss with a reduction in thyroid-releasing hormone (TRH) and TSH (213). These fluctuations in weight appear to also be related to observed fluctuations in $\mathrm{GnIH}$, with changes in circulating $\mathrm{TH}$ concentrations inducing the inverse expression of $\mathrm{GnIH}$ (122). However, to the best of our knowledge, a direct effect of GnIH on the thyroid gland is not known, and the expression of the GnIH-R in follicular cells has not been reported. Nonetheless, it is well documented that hyperthyroidism ultimately leads to a net fat loss through an elevation in resting energy expenditure, decreased cholesterol levels, and increased lipolysis and gluconeogenesis (reviewed by: 214, 215), which could lead to reproductive dysfunction. Under fasting conditions, a decline in pituitary Dio2 levels was observed, leading to an inactivation of the HPG axis (216). Simultaneously, hypothalamic Dio2 levels were found to increase (216), resulting in an elevation in NPY and AgRP in the ARC and the inhibition of TRH production in the PVN (217). This likely occurs to defend energy stores $(218,219)$, stimulating feed intake to restore homeostasis. In fact, administration of leptin and alpha-melanocortin-stimulating hormone $(\alpha-\mathrm{MSH})$ restored TRH levels to normal following the fasting-induced decline (220-223). As leptin has been found to be correlated with body mass index (BMI) and TSH levels (224), this adipokine inhibits the orexigenic branch of the melanocortin system while stimulating POMC $(222,225)$. These stimulatory effects of leptin on TRH occur in both a direct mechanism in the PVN and the indirect mechanism in the ARC, acting through the melanocortin system (222). Intriguingly, in Dio2-KO mice, post-fasting feeding behavior did not return to normal levels (217), suggesting that $T_{3}$ activation of the orexigenic peptides may be more critical than $\mathrm{GnIH}$ in restoring this behavior.

As elevated TH levels are known to activate GnRH neurons and indirectly suppress the activity of GnIH (226-228), it is unsurprising that GnIH mRNA levels decline with the administration of $\mathrm{T}_{4}$ and increase during periods of low circulating levels (122). In fact, $\mathrm{GnIH}-\mathrm{KO}$ prevented the delay in pubertal onset typically associated with hypothyroidism (122). Furthermore, as is discussed in more detail in the following section, while GnIH has been shown to decrease insulin production, TH are known to exert an opposite role (229), leading to alterations in leptin concentrations. Thus, we hypothesize that leptin may be indirectly downregulated in the presence of $\mathrm{GnIH}$, and therefore the re-activation of the HPT axis via leptin depends on the downregulation of $\mathrm{GnIH}$ observed under fasting conditions.

\section{BEYOND NEUROENDOCRINE FUNCTIONS, GnIH AND ITS RECEPTOR PARTICIPATE IN THE PERIPHERAL REGULATION OF PHYSIOLOGICAL PROCESSES}

\section{Peripheral Control of Reproduction}

Although it is clear that $\mathrm{GnIH}$ and its receptor are key to the hypothalamic control of reproduction, the presence of the GnIH$\mathrm{R}$ at the lower level of the HPG axis (gonads) has also been reported in avian species, including the Japanese quail, the European starling, the white-crowned sparrow (10), and the domestic chicken $(7,230)$, as well as various fish species including clownfish (57), Nile tilapia (56), Indian carp (61), common carp (54), zebrafish (51), and goldfish (49), and the rat $(13,15)$. Additionally, the GnIH-R has been identified in the ovary of humans (30), swine (33), felines (35), tongue sole (60), 
and in the testis of Syrian hamsters (26) and house sparrows (11) (Table 1). Furthermore, treatment with $\mathrm{GnIH}$ was shown to effectively shut down reproduction in the ovary and testis not only by indirectly reducing gonadotropins release from the pituitary as previously discussed, but also directly by decreasing cell viability in the ovary and reducing the levels of testosterone in the testis $(5,8,10,11,46,51)$. In fact, the GnIH-R has been found to play a role in the downregulation of steroidogenesis $(7,10,11,30,46,51)$. In humans, $\mathrm{GnIH}$ has been shown to downregulate the production of steroidogenic acute regulatory (StAR) protein, while the GnIH-R antagonist (RF9) was able to partly block this effect (30). Beyond steroidogenic enzymes, by suppressing glucose uptake (to be discussed in the following section), which normally promotes cholesterol uptake and thus metabolic substrates to germ cells (231, 232), GnIH may also reduce substrate availability resulting in a decline in sex steroid production in mammals (142). In turn, the inhibitory effect of $\mathrm{GnIH}$ produced in the gonads results in a decline in spermatogenesis $(10,26)$ or a decline in the viability of pre-hierarchical follicles leading to impaired follicular maturation (46). Similar to the anterior pituitary, treatment with estradiol and/or progesterone also downregulates the expression of the GnIH-R in the chicken ovary (46). Thus, the impact of GnIH on the inhibition of the HPG axis may become less influential once the animal reaches sexual maturity.

\section{Peripheral Metabolic Control}

Similar to reproduction, recent evidence also points to a broader role for $\mathrm{GnIH}$ on peripheral tissues, especially as it relates to energy storage and availability. Recently, high levels of $\mathrm{GnIH}$ mRNA have been confirmed in the eye, while low levels were observed in the colon, stomach, ileum, muscle, kidney, and spleen (162). Interestingly, the expression pattern of $\mathrm{GnIH}$ in these peripheral tissues was similar to that of its receptor (162). Nonetheless, since this is a relatively new field of research, most studies described in the following section are based on the peripheral administration of exogenous $\mathrm{GnIH}$ rather than on the activity of endogenous GnIH itself.

\section{Adipose Tissue}

Although GnIH may not be produced in the adipose tissue, its receptor was shown to be present on human fat cells, suggesting a direct role for $\mathrm{GnIH}$ or its orthologues on adiposity (29). Interestingly, the initial focus was placed on white adipose tissue (WAT) due to its association with energy storage (233). However, it was recently reported that GnIH treatment inhibits the activity of BAT (143), which plays a critical role in energy expenditure through thermogenesis (reviewed by: 234, 235).

In terms of WAT, circulating leptin concentrations can be used as an indirect measure of fat accumulation (96, 236-238). For example, higher leptin concentrations are observed in fat or ad libitum fed Syrian hamsters compared to their respective lean or feed-restricted counterparts (239). Of interest, leptin is known to reduce feed intake (240) and is considered anorexigenic (241). This activity opposes the role of $\mathrm{GnIH}$ on appetite control discussed earlier and highlights a possible antagonistic effect between leptin and GnIH (178). This relationship is further emphasized in ob/ob mice, which lack a functional leptin gene (181). Without this WAT regulator, rats demonstrated an elevation in body weight $(242,243)$, similar to that observed in GnIH treated mice (143).

As described previously, both leptin and GnIH activate the PI3K/Akt signalling pathway in the hypothalamus, a pathway also used during insulin-mediated glucose uptake in the adipose tissue (142), thus, raising the possibility of an interaction between, GnIH, leptin, and insulin in the regulation of glucose uptake. Since GnIH-treated male hamsters had higher levels of leptin and insulin compared to controls (96), it is possible that this resulted in increased adiposity (142), leading to increased insulin resistance (reviewed by: 244). However, this effect was not observed in female hamsters (96). In fact, it appears that the effect of $\mathrm{GnIH}$ may be dose-dependent as 2,000 and $20 \mathrm{ng}$ induced a decline and increase in glucose levels, respectively, with a concomitant elevation in insulin receptor and GLUT8 proteins under the lowest GnIH dose only (142). Thus, GnIH may regulate insulin sensitivity, at least in male mice. As the study by Cázarez-Marquez et al. (96) used significantly higher $\mathrm{GnIH}$ levels $(105-\mu \mathrm{g})$, a possible $\mathrm{GnIH}$ threshold may exist with supraphysiological doses eliciting opposite effects.

\section{Pancreas}

As described in the previous section, $\mathrm{GnIH}$ has been hypothesized to regulate fat accumulation in adipose tissue through the mediation of increased nutrient uptake, including glucose and triglycerides (142). In fact, when injected intraperitoneally, GnIH has been found to primarily co-localize with glucagon in $\alpha$-cells, while its receptor, although present in both cell types, is primarily co-localized with insulin in $\beta$-cells of pancreatic islets (153), strongly suggesting an involvement in glucose homeostasis. Essentially, GnIH supports $\alpha$ cell survival and hyperplasia through activation of the GnIH-R present in these cells, which triggers the AKT and ERK1/2 pathways (186), leading to an increase in glucagon and feed intake. When glycemia is elevated, $\beta$-cells would normally release insulin to offset the imbalance, restore glucose homeostasis, and reduce feed intake (reviewed by: 245). However, recent evidence demonstrated that chronic and acute doses of GnIH increase blood glucose levels while simultaneously reducing insulin secretion. With the colocalization of $\mathrm{GnIH}$ and glucagon, it is likely $\mathrm{GnIH}$ can promote hyperglycemia in rats $(153,246)$. The direct blockade of insulin has been hypothesized to occur through $\mathrm{G \alpha}_{\mathrm{i}}$ and the inhibition of the ACcAMP-PKA pathway $(153,247)$. This hypothesis is further supported by the reduced insulin sensitivity with chronic $\mathrm{GnIH}$ treatment, characterized by a decline in insulin receptor and GLUT4 in the adipose tissue $(142,153)$. Intriguingly, since insulin is able to relay information regarding body fat status to the central nervous system (reviewed by: 248, 249), inhibition via GnIH further supports a multipronged impact through which $\mathrm{GnIH}$ promotes fat accumulation and an elevation in body weight, associated with increased feed intake (see previous section). Furthermore, kisspeptin has also been reported to stimulate glucose production with an increased glucose tolerance to prevent the onset of hyperglycemic disorders (250) via its receptor. As this effect is absent in GPR54-KO mice (251), it is possible that cross-activation 


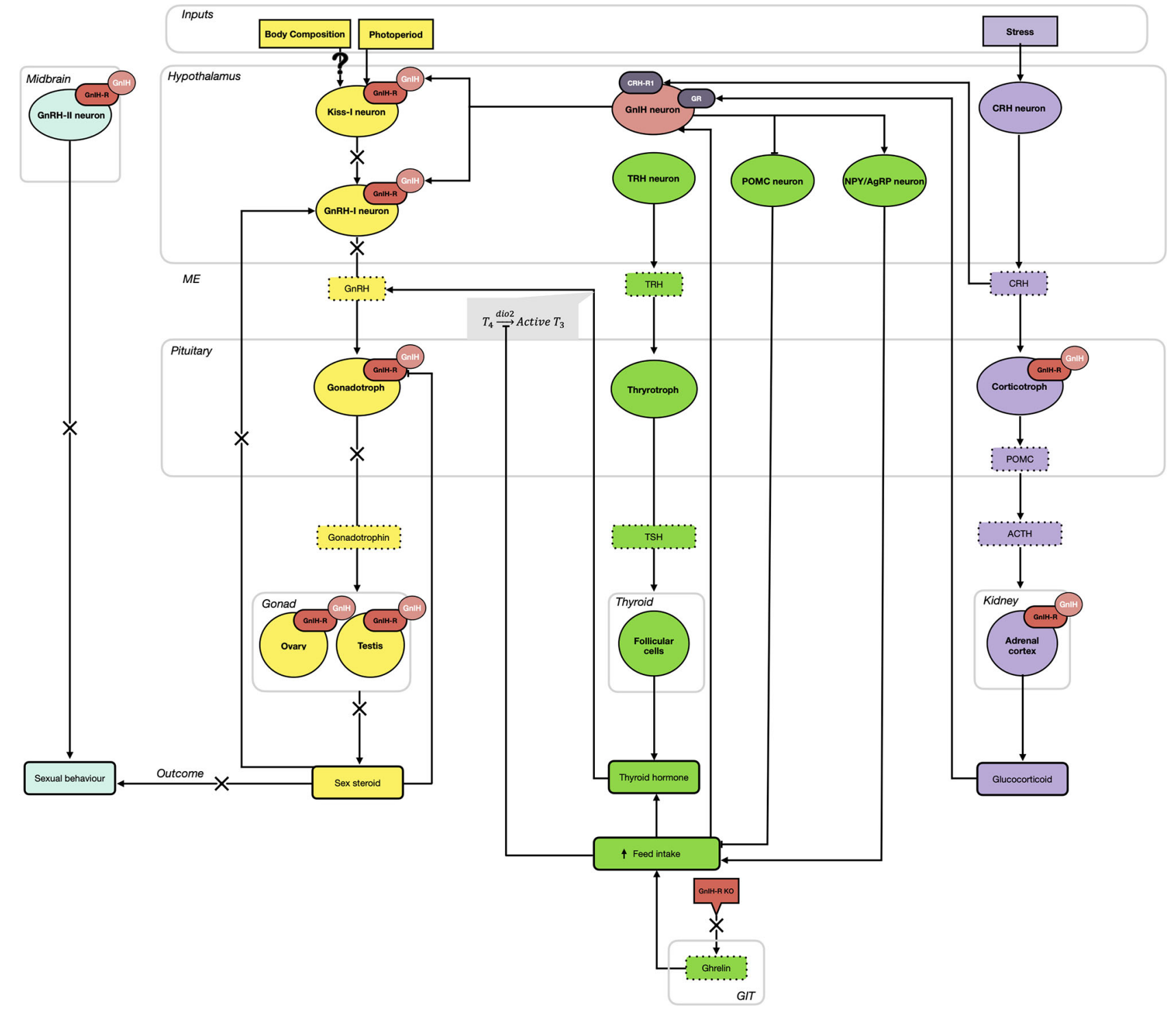

FIGURE 1 | The hypothalamo-pituitary-gonadal (HPG; yellow), thyroid/metabolic (HPT; green), and adrenal (HPA; purple) axes are highly integrated via the activity of gonadotropin-inhibitory hormone $(\mathrm{Gn} \mid \mathrm{H})$ and its receptor $(\mathrm{Gn} / \mathrm{H}-\mathrm{R})$. As part of the HPG axis, GnlH neurons elicit an inhibitory effect on gonadotropin-releasing hormone I (GnRH-I) neurons (hypothalamus) and gonadotroph cells (pituitary gland) in all species, in addition to suppressing the activity of kisspeptin (Kiss-1) neurons in mammalian species (hypothalamus). Additional $\mathrm{GnIH-Rs}$ on $\mathrm{GnRH}-\mathrm{Il}$ neurons in the midbrain contribute to the inhibition of sexual behaviors. In seasonal breeders, photoperiod influences the expression of $\mathrm{GnIH}$, with short day (SD) lengths elevating $\mathrm{G} n \mathrm{lH}$ and inhibiting reproduction, while long day (LD) lengths diminish GnIH expression and permits the progression of sexual maturation, via gonadotropin production. Acting at the level of the gonads (ovary and testis), the production of sex steroids further downregulates GnlH-R expressed in the pituitary gland. Simultaneously, GnlH neurons stimulate the orexigenic peptides, neuropeptide Y (NPY) and agouti-related peptide (AgRP), and downregulate the anorexigenic peptide pro-opiomelanocortin (POMC). Overall, this results in an increase in feed intake, promoting an upregulation of the HPT axis. Ghrelin from the gastrointestinal tract (GIT) also contributes to this elevation in feed intake and knockout (KO) of the GnlH-R can downregulate this pathway. Active conversion of thyroid hormones $\left(T_{4} \rightarrow T_{3}\right)$ stimulates the release of $G n R H$ from the hypothalamus, thus activating the HPG axis. Finally, the HPA (stress) axis also provides input to $\mathrm{GnIH}$ neurons. While $\mathrm{GnlH}$ can bind to pituitary corticotropes and the adrenal cortex to promote an elevation in adrenocorticotropic hormone (ACTH) and glucocorticoids, respectively, elevations in glucocorticoids positively feedback on GnlH neurons. This results in an inhibitory effect on reproductive activity, hypothesized to shift resources away from this energetically expensive process and towards managing the stressor.

by various members of the RFamide family, including $\mathrm{GnIH}$, can occur. This is of particular interest as insulin has been reported to be a mediator between nutritional status and reproductive success (252), and significant fluctuations in glucose levels can be lethal (reviewed by: 253).

\section{CONCLUSION}

Since its initial discovery over 20 years ago, the roles and importance of $\mathrm{GnIH}$ and its receptor have significantly expanded. As shown in Figure 1, GnIH, via its receptor, not 
only directly inhibits the synthesis and release of GnRH and gonadotropins but also participates in the integration of multiple internal and external cues to control reproduction. Specifically, we propose that $\mathrm{GnIH}$ is responsible for modulating body composition and energy status and thus partitioning nutrients away from reproduction. This is achieved in part by stimulating feed intake via the melanocortin system, which in turn inhibits the induced release of GnRH in the ME by THs. Furthermore, we also propose that the negative impact of stress on reproduction is mediated in part via $\mathrm{GnIH}$, as it is upregulated by both hypothalamic $\mathrm{CRH}$ and circulating glucocorticoids while also stimulating the expression of POMC in pituitary corticotrophs and glucocorticoids in the adrenal cortex. This results in a complex central integration between the HPG, HPT and HPA axes to allow or preclude reproduction from proceeding (Figure 1). In addition, recent evidence also suggests that
$\mathrm{GnIH}$ and its receptor participate in the regulation of peripheral metabolic processes (Figure 2). In the pancreatic islets, $\mathrm{GnIH}$ produced by $\alpha$-cells acts in a paracrine manner on its receptor present on $\beta$-cells to inhibit the production of insulin, thus counteracting the effect of THs and leptin and promoting feed intake while reducing gluconeogenesis and glycogenesis in the liver (Figure 2). Interestingly, the presence of the GnIH-R in adipose tissue suggests a more complex role on energy partitioning, requiring further investigation (Figure 2). Nonetheless, with the known promiscuity between members of the RF-amide family and their receptors, it is also possible that alternative ligands and receptors are also involved, opening new avenues for potential therapeutic applications.

Ultimately, while our understanding of the individual physiological roles played by $\mathrm{GnIH}$ and its receptor has been extensively investigated over the last two decades, integrative

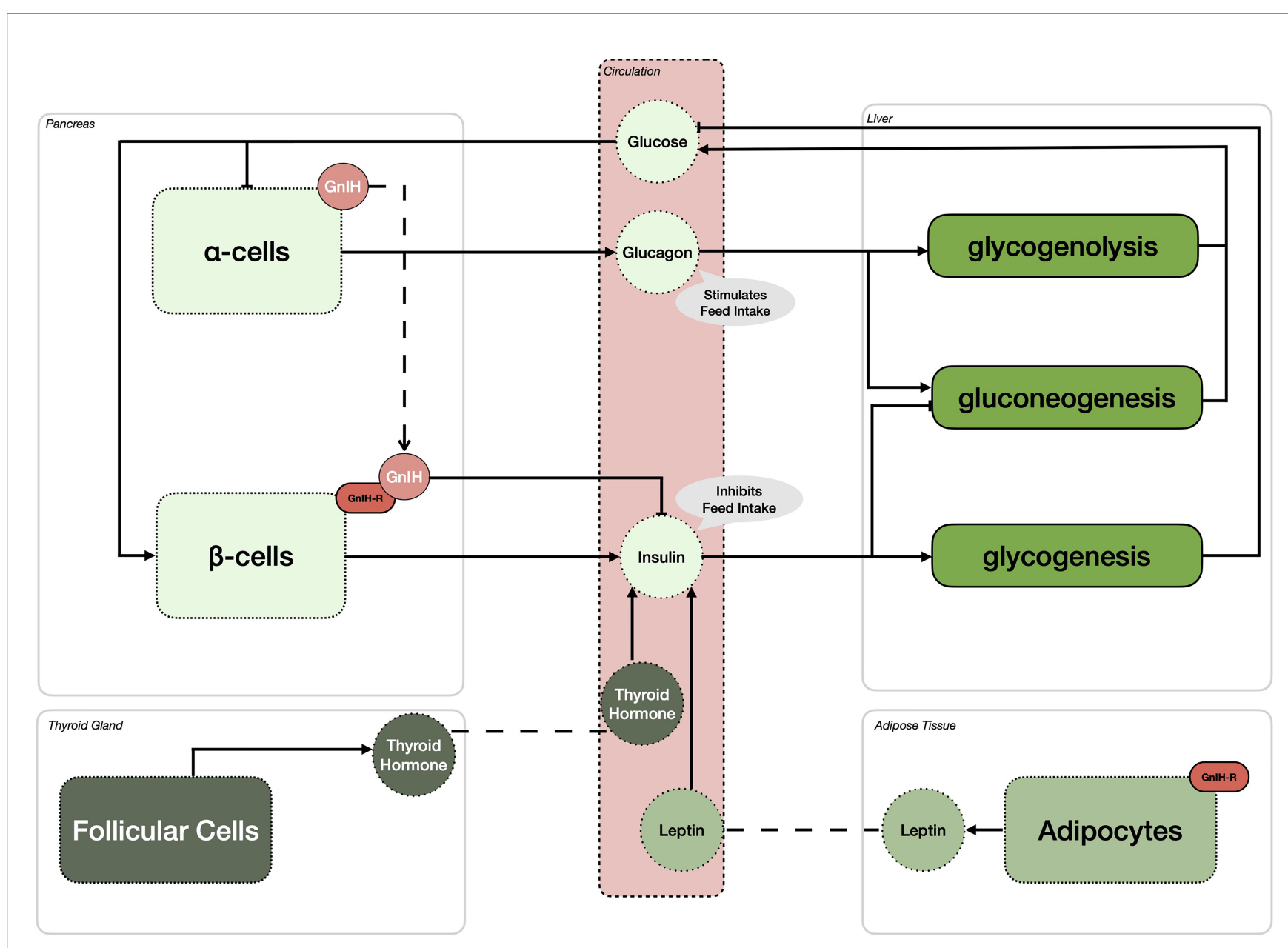

FIGURE 2 | Gonadotropin-inhibitory hormone $(\mathrm{GnIH})$ and its receptor (GnIH-R) impact metabolic control and energy partitioning in various peripheral organs. In the pancreas, $\mathrm{GnlH}$ is expressed in alpha cells ( $\alpha$-cells), while $\mathrm{GnlH}-\mathrm{R}$ is expressed in the beta cells ( $\beta$-cells). It is hypothesized that $\mathrm{GnlH}$ binding to its receptor will inhibit the production of insulin in $\beta$-cells, thus stimulating feed intake. In an effort to achieve homeostasis, high glucose levels stimulate the production of insulin leading to the stimulation of glycogenesis and inhibition of gluconeogenesis in the liver. However, in periods of low glucose availability, $\alpha$-cells increase their production of glucagon, leading to the stimulation of feed intake, similar to the activity of $\mathrm{Gn} l \mathrm{H}$. In addition, glucagon stimulates both glycogenolysis and gluconeogenesis, elevating the circulating levels of glucose. While the expression and presence of GnlH has yet to be reported in adipocytes, GnlH-R is. Thus, it is hypothesized that GnIH can influence circulating leptin concentrations, an hormone known to oppose the action of GnlH on insulin, thereby downregulating feed intake. As for leptin, thyroid hormones also stimulate the anorexigenic effect of insulin, thus counteracting the effect of GnlH on glucose mediated feed intake. 
functions both centrally and peripherally are relatively recent and open the avenue to a new era of research.

\section{AUTHOR CONTRIBUTIONS}

GB is the lead author who coordinated the contributions of coauthors, elaborated the structure of the manuscript and wrote the main section related to reproduction. $\mathrm{CH}$ contributed to all sections of the manuscript with particular emphasis on metabolic control. $\mathrm{CH}$ also designed the figures and tables. KT was the architect of this review and provided the information as

\section{REFERENCES}

1. Tsutsui K, Saigoh E, Ukena K, Teranishi H, Fujisawa Y, Kikuchi M, et al. A Novel Avian Hypothalamic Peptide Inhibiting Gonadotropin Release. Biochem Biophys Res Commun (2000) 275:661-7. doi: 10.1006/ bbrc. 2000.3350

2. Ogawa S, Parhar IS. Structural and Functional Divergence of Gonadotropin-Inhibitory Hormone From Jawless Fish to Mammals. Front Endocrinol (Lausanne) (2014) 5:1-17. doi: 10.3389/ fendo.2014.00177

3. Tsutsui K, Ubuka T. Gonadotropin-Inhibitory Hormone (GnIH): A New Key Neurohormone Controlling Reproductive Physiology and Behavior. Front Neuroendocrinol (2021) 61:100900. doi: 10.1016/j.yfrne.2021.100900

4. Ubuka T, Morgan K, Pawson AJ, Osugi T, Chowdhury VS, Minakata H, et al. Identification of Human GnIH Homologs, RFRP-1 and RFRP-3, and the Cognate Receptor, GPR147 in the Human Hypothalamic Pituitary Axis. PloS One (2009) 4:1-7. doi: 10.1371/journal.pone.0008400

5. Ubuka T, Ukena K, Sharp PJ, Bentley GE, Tsutsui K. GonadotropinInhibitory Hormone Inhibits Gonadal Development and Maintenance by Decreasing Gonadotropin Synthesis and Release in Male Quail. Endocrinology (2006) 147:1187-94. doi: 10.1210/en.2005-1178

6. Ciccone NA, Sharp PJ, Wilson PW, Dunn IC. Changes in Reproductive Neuroendocrine mRNAs With Decreasing Ovarian Function in Ageing Hens. Gen Comp Endocrinol (2005) 144:20-7. doi: 10.1016/j.ygcen. 2005.04.009

7. Ikemoto T, Park MK. Chicken RFamide-Related Peptide (GnIH) and Two Distinct Receptor Subtypes: Identification, Molecular Characterization, and Evolutionary Considerations. J Reprod Dev (2005) 51:359-77. doi: 10.1262/ jrd. 16087

8. Yin H, Ukena K, Ubuka T, Tsutsui K. A Novel G Protein-Coupled Receptor for Gonadotropin-Inhibitory Hormone in the Japanese Quail (Coturnix Japonica): Identification, Expression and Binding Activity. J Endocrinol (2005) 184:257-66. doi: 10.1677/joe.1.05926

9. Bentley GE, Jensen JP, Kaur GJ, Wacker DW, Tsutsui K, Wingfield JC. Rapid Inhibition of Female Sexual Behavior by Gonadotropin-Inhibitory Hormone (GnIH). Horm Behav (2006) 49:550-5. doi: 10.1016/j.yhbeh. 2005.12.005

10. Bentley GE, Ubuka T, McGuire NL, Chowdhury VS, Morita Y, Yano T, et al. Gonadotropin-Inhibitory Hormone and Its Receptor in the Avian Reproductive System. Gen Comp Endocrinol (2008) 156:34-43. doi: 10.1016/j.ygcen.2007.10.003

11. McGuire NL, Bentley GE. A Functional Neuropeptide System in Vertebrate Gonads: Gonadotropin-Inhibitory Hormone and Its Receptor in Testes of Field-Caught House Sparrow (Passer domesticus). Gen Comp Endocrinol (2010) 166:566-72. doi: 10.1016/j.ygcen.2010.01.010

12. Poling MC, Kauffman AS. Regulation and Function of RFRP-3 (GnIH) Neurons During Postnatal Development. Front Endocrinol (Lausanne) (2015) 6:1-6. doi: 10.3389/fendo.2015.00150

13. Bonini JA, Jones KA, Adham N, Forray C, Artymyshyn R, Durkin MM, et al. Identification and Characterization of Two G Protein-Coupled Receptors for Neuropeptide FF. J Biol Chem (2000) 275:39324-31. doi: 10.1074/ jbc.M004385200 it pertains to the comparative aspect of this review. All authors contributed to the article and approved the submitted version.

\section{ACKNOWLEDGMENTS}

This review would not have been possible without the support, enthusiasm, and dedication of Professor Kazuyoshi Tsutsui. Dear friend and colleague, your legacy in the field of comparative neuroendocrinology will have a lasting impact. We would also like to acknowledge the contribution of Miss Clara Ziezold for her help in designing the figures and tables and helping organize references.

14. Kriegsfeld LJ, Mei DF, Bentley GE, Ubuka T, Mason AO, Inoue K, et al Identification and Characterization of a Gonadotropin-Inhibitory System in the Brains of Mammals. Proc Natl Acad Sci (2006) 103:2410-5. doi: 10.1073/ pnas.0511003103

15. Hinuma S, Shintani Y, Fukusumi S, Lijima N, Matsumoto Y, Hosoya M, et al. New Neuropeptides Containing Carboxy-Terminal RFamide and Their Receptor in Mammals. Nat Cell Biol (2000) 2:703-8. doi: 10.1038/35036326

16. Liu Q, Guan XM, Martin WJ, McDonald TP, Clements MK, Jiang Q, et al. Identification and Characterization of Novel Mammalian Neuropeptide FFLike Peptides That Attenuate Morphine-Induced Antinociception. J Biol Chem (2001) 276:36961-9. doi: 10.1074/jbc.M105308200

17. Quillet R, Ayachi S, Bihel F, Elhabazi K, Ilien B, Simonin F. RF-Amide Neuropeptides and Their Receptors in Mammals: Pharmacological Properties, Drug Development and Main Physiological Functions. Pharmacol Ther (2016) 160:84-132. doi: 10.1016/j.pharmthera.2016.02.005

18. Ubuka T, Kim S, Huang Y, Reid J, Jiang J, Osugi T, et al. GonadotropinInhibitory Hormone Neurons Interact Directly With GonadotropinReleasing Hormone-I and -II Neurons in European Starling Brain. Endocrinology (2008) 149:268-78. doi: 10.1210/en.2007-0983

19. Wang Q, Qi X, Guo Y, Li S, Zhang Y, Liu X, et al. Molecular Identification of GnIH/GnIHR Signal and its Reproductive Function in Protogynous Hermaphroditic Orange-Spotted Grouper (Epinephelus Coioides). Gen Comp Endocrinol (2015) 216:9-23. doi: 10.1016/j.ygcen.2015.04.016

20. Yoshida H, Habata Y, Hosoya M, Kawamata Y, Kitada C, Hinuma S. Molecular Properties of Endogenous RFamide-Related Peptide-3 and Its Interaction With Receptors. Biochim Biophys Acta Mol Cell Res (2003) 1593:151-7. doi: 10.1016/S0167-4889(02)00389-0

21. Elshourbagy NA, Ames RS, Fitzgerald LR, Foley JJ, Chambers JK, Szekeres PG, et al. Receptor for the Pain Modulatory Neuropeptides FF and AF is an Orphan G Protein-Coupled Receptor. J Biol Chem (2000) 275:25965-71. doi: 10.1074/jbc.M004515200

22. Thorson JF, Prezotto LD, Cardoso RC, Sharpton SM, Edwards JF, Welsh $\mathrm{TH}$, et al. Hypothalamic Distribution, Adenohypophyseal Receptor Expression, and Ligand Functionality of RFamide-Related Peptide 3 in the Mare During the Breeding and Nonbreeding Seasons. Biol Reprod (2014) 90:1-9. doi: 10.1095/biolreprod.113.112185

23. Henningsen JB, Poirel VJ, Mikkelsen JD, Tsutsui K, Simonneaux V, Gauer F. Sex Differences in the Photoperiodic Regulation of RF-Amide Related Peptide (RFRP) and its Receptor GPR147 in the Syrian Hamster. J Comp Neurol (2016) 524:1825-38. doi: 10.1002/cne.23924

24. Rizwan MZ, Poling MC, Corr M, Cornes PA, Augustine RA, Quennell JH, et al. RFamide-Related Peptide-3 Receptor Gene Expression in $\mathrm{GnRH}$ and Kisspeptin Neurons and GnRH-Dependent Mechanism of Action. Endocrinology (2012) 153:3770-9. doi: 10.1210/en.2012-1133

25. Gibson EM, Humber SA, Jain S, Williams WP, Zhao S, Bentley GE, et al. Alterations in RFamide-Related Peptide Expression are Coordinated With the Preovulatory Luteinizing Hormone Surge. Endocrinology (2008) 149:4958-69. doi: 10.1210/en.2008-0316

26. Zhao S, Zhu E, Yang C, Bentley GE, Tsutsui K, Kriegsfeld LJ. RFamideRelated Peptide and Messenger Ribonucleic Acid Expression in Mammalian Testis: Association With the Spermatogenic Cycle. Endocrinology (2010) 151:617-27. doi: 10.1210/en.2009-0978 
27. Ubuka T, Inoue K, Fukuda Y, Mizuno T, Ukena K, Kriegsfeld LJ, et al. Identification, Expression, and Physiological Functions of Siberian Hamster Gonadotropin-Inhibitory Hormone. Endocrinology (2012) 153:373-85. doi: 10.1210/en.2011-1110

28. Dardente H, Birnie M, Lincoln GA, Hazlerigg DG. RFamide-Related Peptide and its Cognate Receptor in the Sheep: cDNA Cloning, mRNA Distribution in the Hypothalamus and the Effect of Photoperiod. J Neuroendocrinol (2008) 20:1252-9. doi: 10.1111/j.1365-2826.2008.01784.x

29. Van Harmelen V, Dicker A, Sjölin E, Blomqvist L, Wirén M, Hoffstedt J, et al. Effects of Pain Controlling Neuropeptides on Human Fat Cell Lipolysis. Int J Obes (2010) 34:1333-40. doi: 10.1038/ijo.2010.46

30. Oishi H, Klausen C, Bentley GE, Osugi T, Tsutsui K, Gilks CB, et al. The Human Gonadotropin-Inhibitory Hormone Ortholog RFamide-Related Peptide-3 Suppresses Gonadotropin-Induced Progesterone Production in Human Granulosa Cells. Endocrinology (2012) 153:3435-45. doi: 10.1210/ en.2012-1066

31. Wahab F, Drummer C, Schlatt S, Behr R. Dynamic Regulation of Hypothalamic DMXL2, KISS1, and RFRP Expression During Postnatal Development in Non-Human Primates. Mol Neurobiol (2017) 54:8447-57. doi: 10.1007/s12035-016-0329-x

32. Li X, Su J, Lei Z, Zhao Y, Jin M, Fang R, et al. Gonadotropin-Inhibitory Hormone $(\mathrm{GnIH})$ and Its Receptor in the Female Pig: CDNA Cloning, Expression in Tissues and Expression Pattern in the Reproductive Axis During the Estrous Cycle. Peptides (2012) 36:176-85. doi: 10.1016/ j.peptides.2012.05.008

33. Li X, Su J, Fang R, Zheng L, Lei R, Wang X, et al. The Effects of RFRP-3, the Mammalian Ortholog of $\mathrm{GnIH}$, on the Female Pig Reproductive Axis In Vitro. Mol Cell Endocrinol (2013) 372:65-72. doi: 10.1016/j.mce.2013.03.015

34. Thorson JF, Heidorn NL, Ryu V, Czaja K, Nonneman DJ, Barb CR, et al. Relationship of Neuropeptide FF Receptors With Pubertal Maturation of Gilts. Biol Reprod (2017) 96:617-34. doi: 10.1095/biolreprod.116.144998

35. Wilsterman K, Bentley GE, Comizzoli P. RFRP3 Influences Basal Lamina Degradation, Cellular Death, and Progesterone Secretion in Cultured Preantral Ovarian Follicles From the Domestic Cat. PeerJ (2019) 7:1-26. doi: $10.7717 /$ peerj.7540

36. Iwasa T, Matsuzaki T, Murakami M, Kinouchi R, Osugi T, Gereltsetseg G, et al. Developmental Changes in the Mammalian Gonadotropin-Inhibitory Hormone (GnIH) Ortholog RFamide-Related Peptide (RFRP) and its Cognate Receptor GPR147 in the Rat Hypothalamus. Int J Dev Neurosci (2012) 30:31-7. doi: 10.1016/j.ijdevneu.2011.10.003

37. Kovács A, László K, Gálosi R, Ollmann T, Péczely L, Zagoracz O, et al. Intraamygdaloid Microinjection of RFamide-Related Peptide-3 Decreases Food Intake in Rats. Brain Res Bull (2014) 107:61-8. doi: 10.1016/ j.brainresbull.2014.07.002

38. Quennell JH, Rizwan MZ, Relf HL, Anderson GM. Developmental and Steroidogenic Effects on the Gene Expression of RFamide Related Peptides and Their Receptor in the Rat Brain and Pituitary Gland. J Neuroendocrinol (2010) 22:309-16. doi: 10.1111/j.1365-2826.2010.01963.x

39. Leon S, Velasco I, Vázquez MJ, Barroso A, Beiroa D, Heras V, et al. SexBiased Physiological Roles of NPFF1R, the Canonical Receptor of RFRP-3, in Food Intake and Metabolic Homeostasis Revealed by Its Congenital Ablation in Mice. Metabolism (2018) 87:87-97. doi: 10.1016/j.metabol.2018.07.003

40. Poling MC, Kim J, Dhamija S, Kauffman AS. Development, Sex Steroid Regulation, and Phenotypic Characterization of RFamide-Related Peptide (Rfrp) Gene Expression and RFamide Receptors in the Mouse Hypothalamus. Endocrinology (2012) 153:1827-40. doi: 10.1210/en.20112049

41. Sukhbaatar U, Kanasaki H, Mijiddorj T, Oride A, Miyazaki K. Expression of Gonadotropin-Inhibitory Hormone Receptors in Mouse Pituitary Gonadotroph L $\beta \mathrm{t} 2$ Cells and Hypothalamic Gonadotropin-Releasing Hormone-Producing GT1-7 Cells. Endocr J (2014) 61:25-34. doi: 10.1507/ endocrj.EJ13-0238

42. Son YL, Ubuka T, Millar RP, Kanasaki H, Tsutsui K. GonadotropinInhibitory Hormone Inhibits Gnrh-Induced Gonadotropin Subunit Gene Transcriptions by Inhibiting AC/cAMP/PKA-Dependent ERK Pathway in Lßt2 Cells. Endocrinology (2012) 153:2332-43. doi: 10.1210/en.2011-1904

43. Chen J, Huang S, Zhang J, Li J, Wang Y. Characterization of the Neuropeptide FF (NPFF) Gene in Chickens: Evidence for a Single
Bioactive NPAF Peptide Encoded by the NPFF Gene in Birds. Domest Anim Endocrinol (2020) 72:1-10. doi: 10.1016/j.domaniend.2020.106435

44. Shimizu M, Bédécarrats GY. Activation of the Chicken GonadotropinInhibitory Hormone Receptor Reduces Gonadotropin Releasing Hormone Receptor Signaling. Gen Comp Endocrinol (2010) 167:331-7. doi: 10.1016/ j.ygcen.2010.03.029

45. McConn BR, Yi J, Gilbert ER, Siegel PB, Chowdhury VS, Furuse M, et al. Stimulation of Food Intake After Central Administration of GonadotropinInhibitory Hormone is Similar in Genetically Selected Low and High Body Weight Lines of Chickens. Gen Comp Endocrinol (2016) 232:96-100. doi: 10.1016/j.ygcen.2016.01.004

46. Maddineni S, Ocon-Grove O, Krzysik-Walker S, Hendricks G, Ramachandran R. Gonadotropin-Inhibitory Hormone (GnIH) Receptor Gene is Expressed in the Chicken Ovary: Potential Role of GnIH in Follicular Maturation. Reproduction (2008) 135:267-74. doi: 10.1530/REP07-0369

47. Brady K, Long JA, Liu HC, Porter TE. Differences in In Vitro Responses of the Hypothalamo-Pituitary-Gonadal Hormonal Axis Between Low- and High-Egg-Producing Turkey Hens. Poult Sci (2020) 99:6221-32. doi: $10.1016 /$ j.psj.2020.08.048

48. Qi X, Zhou W, Li S, Lu D, Yi S, Xie R, et al. Evidences for the Regulation of GnRH and GTH Expression by GnIH in the Goldfish, Carassius Auratus. Mol Cell Endocrinol (2013) 366:9-20. doi: 10.1016/j.mce.2012.11.001

49. Qi X, Zhou W, Lu D, Wang Q, Zhang H, Li S, et al. Sexual Dimorphism of Steroidogenesis Regulated by Gnih in the Goldfish, Carassius Auratus. Biol Reprod (2013) 88:1-7. doi: 10.1095/biolreprod.112.105114

50. Moussavi M, Wlasichuk M, Chang JP, Habibi HR. Seasonal Effect of GnIH on Gonadotrope Functions in the Pituitary of Goldfish. Mol Cell Endocrinol (2012) 350:53-60. doi: 10.1016/j.mce.2011.11.020

51. Zhang Y, Li S, Liu Y, Lu D, Chen H, Huang X, et al. Structural Diversity of the Gnih/Gnih Receptor System in Teleost: Its Involvement in Early Development and the Negative Control of LH Release. Peptides (2010) 31:1034-43. doi: 10.1016/j.peptides.2010.03.003

52. Spicer OS, Zmora N, Wong TT, Golan M, Levavi-Sivan B, Gothilf Y, et al. The Gonadotropin-Inhibitory Hormone (LPXRFa) System's Regulation of Reproduction in the Brain-Pituitary Axis of the Zebrafish (Danio Rerio)T. Biol Reprod (2017) 96:1031-42. doi: 10.1093/biolre/iox032

53. Song Y, Peng W, Luo J, Zhu Z, Hu W. Organization of the GonadotropinInhibitory Hormone (LPXRFa) System in the Brain of Zebrafish (Danio Rerio). Gen Comp Endocrinol (2021) 304:113722. doi: 10.1016/ j.ygcen.2021.113722

54. Peng W, Cao M, Chen J, Li Y, Wang Y, Zhu Z, et al. GnIH Plays a Negative Role in Regulating GtH Expression in the Common Carp, Cyprinus Carpio L. Gen Comp Endocrinol (2016) 235:18-28. doi: 10.1016/j.ygcen.2016.06.001

55. Kumar P, Wisdom KS, Bhat IA, Pathakota GB, Nayak SK, Reang D, et al. Molecular Characterization of Gonadotropin-Inhibitory Hormone (GnIH) Gene and Effect of Intramuscular Injection of GnIH Peptide on the Reproductive Axis in Catla Catla. Anim Biotechnol (2020) 31:335-49. doi: 10.1080/10495398.2019.1597730

56. Biran J, Golan M, Mizrahi N, Ogawa S, Parhar IS, Levavi-Sivan B. LPXRFa, the Piscine Ortholog of GnIH, and LPXRF Receptor Positively Regulate Gonadotropin Secretion in Tilapia (Oreochromis Niloticus). Endocrinology (2014) 155:4391-401. doi: 10.1210/en.2013-2047

57. Choi YJ, Habibi HR, Choi CY. Profiles of Gonadotropin-Inhibitory Hormone and Melatonin During the Sex Change and Maturation of Cinnamon Clownfish, Amphiprion Melanopus. Biochem Biophys Res Commun (2016) 475:189-93. doi: 10.1016/j.bbrc.2016.05.073

58. Choi YJ, Habibi HR, Kil GS, Jung MM, Choi CY. Effect of Cortisol on Gonadotropin Inhibitory Hormone $(\mathrm{GnIH})$ in the Cinnamon Clownfish, Amphiprion Melanopus. Biochem Biophys Res Commun (2017) 485:342-8. doi: 10.1016/j.bbrc.2017.02.078

59. Shahjahan M, Ikegami T, Osugi T, Ukena K, Doi H, Hattori A, et al. Synchronised Expressions of LPXRFamide Peptide and its Receptor Genes: Seasonal, Diurnal and Circadian Changes During Spawning Period in Grass Puffer. J Neuroendocrinol (2011) 23:39-51. doi: 10.1111/j.1365-2826. 2010.02081.x

60. Wang S, Wang B, Chen S. Spexin in the Half-Smooth Tongue Sole (Cynoglossus Semilaevis): Molecular Cloning, Expression Profiles, and 
Physiological Effects. Fish Physiol Biochem (2018) 44:829-39. doi: 10.1007/ s10695-018-0472-6

61. Kumar P, Kumar M, Wisdom KS, Pathakota GB, Nayak SK, Reang D, et al. Characterization, Docking and Molecular Dynamics Simulation of Gonadotropin-Inhibitory Hormone Receptor (GnIHR2) in Labeo Catla. Cell Physiol Biochem (2020) 54:825-41. doi: 10.33594/000000272

62. Mollereau C, Mazarguil H, Marcus D, Quelven I, Kotani M, Lannoy V, et al. Pharmacological Characterization of Human NPFF1 and NPFF2 Receptors Expressed in CHO Cells by Using NPY Y1 Receptor Antagonists. Eur J Pharmacol (2002) 451:245-56. doi: 10.1016/S0014-2999 (02)02224-0

63. Wang B, Yang G, Xu Y, Li W, Liu X. Recent Studies of LPXRFa Receptor Signaling in Fish and Other Vertebrates. Gen Comp Endocrinol (2019) 277:3-8. doi: 10.1016/j.ygcen.2018.11.011

64. Gouardères C, Mazarguil H, Mollereau C, Chartrel N, Leprince J, Vaudry H, et al. Functional Differences Between NPFF1 and NPFF2 Receptor Coupling: High Intrinsic Activities of RFamide-Related Peptides on Stimulation of [35S]Gtprs Binding. Neuropharmacology (2007) 52:376-86. doi: 10.1016/ j.neuropharm.2006.07.034

65. Oishi S, Misu R, Tomita K, Setsuda S, Masuda R, Ohno H, et al. Activation of Neuropeptide FF Receptors by Kisspeptin Receptor Ligands. ACS Med Chem Lett (2011) 2:53-7. doi: 10.1021/ml1002053

66. Nguyen T, Marusich J, Li JX, Zhang Y. Neuropeptide FF and Its Receptors: Therapeutic Applications and Ligand Development. J Med Chem (2020) 63:12387-402. doi: 10.1021/acs.jmedchem.0c00643

67. Moulédous L, Barthas F, Zajac JM. Opposite Control of Body Temperature by NPFF1 and NPFF2 Receptors in Mice. Neuropeptides (2010) 44:453-6. doi: 10.1016/j.npep.2010.05.003

68. Ayachi S, Simonin F. Involvement of Mammalian RF-Amide Peptides and Their Receptors in the Modulation of Nociception in Rodents. Front Endocrinol (Lausanne) (2014) 5:1-13. doi: 10.3389/fendo.2014.00158

69. Yano T, Iijima N, Kakihara K, Hinuma S, Tanaka M, Ibata Y. Localization and Neuronal Response of RFamide Related Peptides in the Rat Central Nervous System. Brain Res (2003) 982:156-67. doi: 10.1016/S0006-8993(03) 02877-4

70. Johnson MA, Tsutsui K, Fraley GS. Rat RFamide-Related Peptide-3 Stimulates GH Secretion, Inhibits LH Secretion, and has Variable Effects on Sex Behavior in the Adult Male Rat. Horm Behav (2007) 51:171-80. doi: 10.1016/j.yhbeh.2006.09.009

71. Ubuka T, Ueno M, Ukena K, Tsutsui K. Developmental Changes in Gonadotropin-Inhibitory Hormone in the Japanese Quail (Coturnix Japonica) Hypothalamo-Hypophysial System. J Endocrinol (2003) 178:311-8. doi: 10.1677/joe.0.1780311

72. Ukena K, Ubuka T, Tsutsui K. Distribution of a Novel Avian GonadotropinInhibitory Hormone in the Quail Brain. Cell Tissue Res (2003) 312:73-9. doi: 10.1007/s00441-003-0700-x

73. Osugi T, Ukena K, Bentley GE, O’Brien S, Moore IT, Wingfield JC, et al. Gonadotropin-Inhibitory Hormone in Gambel's White-Crowned Sparrow (Zonotrichia Leucophrys Gambelii): cDNA Identification, Transcript Localization and Functional Effects in Laboratory and Field Experiments. J Endocrinol (2004) 182:33-42. doi: 10.1677/joe.0.1820033

74. Bentley GE, Tsutsui K, Kriegsfeld LJ. Recent Studies of GonadotropinInhibitory Hormone (GnIH) in the Mammalian Hypothalamus, Pituitary and Gonads. Brain Res (2010) 1364:62-71. doi: 10.1016/j.brainres. 2010.10.001

75. Tobari Y, Iijima N, Tsunekawa K, Osugi T, Okanoya K, Tsutsui K, et al. Identification of Gonadotropin-Inhibitory Hormone in the Zebra Finch (Taeniopygia Guttata): Peptide Isolation, cDNA Cloning and Brain Distribution. Peptides (2010) 31:816-26. doi: 10.1016/j.peptides.2010.01.015

76. Clarke IJ, Sari IP, Qi Y, Smith JT, Parkington HC, Ubuka T, et al. Potent Action of RFamide-Related Peptide-3 on Pituitary Gonadotropes Indicative of a Hypophysiotropic Role in the Negative Regulation of Gonadotropin Secretion. Endocrinology (2008) 149:5811-21. doi: 10.1210/en.2008-0575

77. Ukena K, Tsutsui K. Distribution of Novel RFamide-Related Peptide-Like Immunoreactivity in the Mouse Central Nervous System. Neurosci Lett (2001) 300:153-6. doi: 10.1016/S0304-3940(01)01583-X

78. Mason AO, Duffy S, Zhao S, Ubuka T, Bentley GE, Tsutsui K, et al. Photoperiod and Reproductive Condition are Associated With Changes in
RFamide-Related Peptide (RFRP) Expression in Syrian Hamsters (Mesocricetus Auratus). J Biol Rhythms (2010) 25:176-85. doi: 10.1177/ 0748730410368821

79. Angelopoulou E, Quignon C, Kriegsfeld LJ, Simonneaux V. Functional Implications of RFRP-3 in the Central Control of Daily and Seasonal Rhythms in Reproduction. Front Endocrinol (Lausanne) (2019) 10:1-15. doi: $10.3389 /$ fendo.2019.00183

80. Davies PR, Hanyu I. Effect of Temperature and Photoperiod on Sexual Maturation and Spawning of the Common Carp. I. Under Conditions of High Temperature. Aquaculture (1986) 51:277-88. doi: 10.1016/0044-8486 (86)90319-4

81. Goldman BD, Elliott JA. Photoperiodism and Seasonality in Hamsters: Role of the Pineal Gland. In: MH S, editor. Processing of Environmental Information in Vertebrates. New York, NY: Springer (1988).

82. Quintero B, Manzo M, Diaz T, Verde, Benacchio N, Sifontes L. Seasonal Changes in Ovarian Activity and Estrous Behavior of Thoroughbred Mares in a Tropical Environment. Biol Reprod (1995) 52:469-74. doi: 10.1093/ biolreprod/52.monograph_series1.469

83. Taranger GL, Haux C, Hansen T, Stefansson SO, Björnsson BT, Walther BT, et al. Mechanisms Underlying Photoperiodic Effects on Age at Sexual Maturity in Atlantic Salmon, Salmo Salar. Aquaculture (1999) 177:47-60. doi: 10.1016/S0044-8486(99)00068-X

84. Enright WJ, Spicer LJ, Kelly M, Culleton N, Prendiville DJ. Energy Level in Winter Diets of Fallow Deer: Effect on Plasma Levels of Insulin-Like Growth Factor-I and Sex Ratio of Their Offspring. Small Rumin Res (2001) 39:253-9. doi: 10.1016/S0921-4488(00)00199-1

85. Berrill IK, Porter MJR, Smart A, Mitchell D, Bromage NR. Photoperiodic Effects on Precocious Maturation, Growth and Smoltification in Atlantic Salmon, Salmo Salar. Aquaculture (2003) 222:239-52. doi: 10.1016/S00448486(03)00125-X

86. Ubuka T, Bentley GE, Ukena K, Tsutsui K. Melatonin Induces the Expression of Gonadotropin-Inhibitory Hormone in the Avian Brain. Proc Natl Acad Sci USA (2005) 102:3052-7. doi: 10.1073/pnas.0403840102

87. Cowan M, Paullada-Salmerón JA, López-Olmeda JF, Sánchez-Vázquez FJ, Muñoz-Cueto JA. Effects of Pinealectomy on the Neuroendocrine Reproductive System and Locomotor Activity in Male European Sea Bass, Dicentrarchus Labrax. Comp Biochem Physiol Part A Mol Integr Physiol (2017) 207:1-12. doi: 10.1016/j.cbpa.2017.02.008

88. Muñoz-Cueto JA, Paullada-Salmerón JA, Aliaga-Guerrero M, Cowan ME, Parhar IS, Ubuka T. A Journey Through the Gonadotropin-Inhibitory Hormone System of Fish. Front Endocrinol (Lausanne) (2017) 8:1-18. doi: 10.3389/fendo.2017.00285

89. Paullada-Salmerón JA, Loentgen GH, Cowan M, Aliaga-Guerrero M, del C. Rendón-Unceta M, Muñoz-Cueto JA. Developmental Changes and DayNight Expression of the Gonadotropin-Inhibitory Hormone System in the European Sea Bass: Effects of Rearing Temperature. Comp Biochem Physiol Part A Mol Integr Physiol (2017) 206:54-62. doi: 10.1016/j.cbpa.2017.01.009

90. Kim BH, Hur SP, Hyeon JY, Yamashina F, Takemura A, Lee YD. Annual Patterns of Ocular Melatonin Level in the Female Grass Puffer, Takifugu Alboplumbeus: Possible Involvement in Seasonal Reproductive Response. Fish Physiol Biochem (2020) 46:787-801. doi: 10.1007/s10695-019-00749-9

91. Ciccone N, Dunn I, Boswell T, Tsutsui K, Ubuka T, Ukena K, et al. Gonadotrophin Inhibitory Hormone Depresses Gonadotropin Alpha and Follicle-Stimulating Hormone Beta Subunit Expression in the Pituitary of the Domestic Chicken. J Neuroendocrinol (2004) 16:999-1006. doi: 10.1111/ j.1365-2826.2005.01260.x

92. Aliaga-Guerrero M, Paullada-Salmerón JA, Piquer V, Mañanós EL, MuñozCueto JA. Gonadotropin-Inhibitory Hormone in the Flatfish, Solea Senegalensis: Molecular Cloning, Brain Localization and Physiological Effects. J Comp Neurol (2018) 526:349-70. doi: 10.1002/cne.24339

93. Amano M, Moriyama S, Ligo M, Kitamura S, Amiya N, Yamamori K, et al. Novel Fish Hypothalamic Neuropeptides Stimulate the Release of Gonadotrophins and Growth Hormone From the Pituitary of Sockeye Salmon. J Endocrinol (2006) 188:417-23. doi: 10.1677/joe.1.06494

94. Bédécarrats GY, McFarlane H, Maddineni SR, Ramachandran R. Gonadotropin-Inhibitory Hormone Receptor Signaling and its Impact on Reproduction in Chickens. Gen Comp Endocrinol (2009) 163:7-11. doi: 10.1016/j.ygcen.2009.03.010 
95. Bedecarrats GY, Baxter M, Sparling B. An Updated Model to Describe the Neuroendocrine Control of Reproduction in Chickens. Gen Comp Endocrinol (2016) 227:58-63. doi: 10.1016/j.ygcen.2015.09.023

96. Cázarez-Márquez F, Milesi S, Laran-Chich MP, Klosen P, Kalsbeek A, Simonneaux V. Kisspeptin and RFRP3 Modulate Body Mass in Phodopus Sungorus via Two Different Neuroendocrine Pathways. J Neuroendocrinol (2019) 31:0-2. doi: 10.1111/jne.12710

97. Gotlieb N, Baker CN, Moeller J, Kriegsfeld LJ. Time-Of-Day-Dependent Sensitivity of the Reproductive Axis to RFamide-Related Peptide-3 Inhibition in Female Syrian Hamsters. J Neuroendocrinol (2019) 31:1-10. doi: 10.1111/jne.12798

98. Ancel C, Bentsen AH, Sébert ME, Tena-Sempere M, Mikkelsen JD, Simonneaux V. Stimulatory Effect of RFRP-3 on the Gonadotrophic Axis in the Male Syrian Hamster: The Exception Proves the Rule. Endocrinology (2012) 153:1352-63. doi: 10.1210/en.2011-1622

99. Wilson ME, Gordon TP. Short-Day Melatonin Pattern Advances Puberty in Seasonally Breeding Rhesus Monkeys (Macaca Mulatta). J Reprod Fertil (1989) 86:435-44. doi: 10.1530/jrf.0.0860435

100. Ducret E, Anderson GM, Herbison AE. RFamide-Related Peptide-3, a Mammalian Gonadotropin-Inhibitory Hormone Ortholog, Regulates Gonadotropin-Releasing Hormone Neuron Firing in the Mouse. Endocrinology (2009) 150:2799-804. doi: 10.1210/en.2008-1623

101. Sari IP, Rao A, Smith JT, Tilbrook AJ, Clarke IJ. Effect of RF-Amide-Related Peptide- 3 on Luteinizing Hormone and Follicle-Stimulating Hormone Synthesis and Secretion in Ovine Pituitary Gonadotropes. Endocrinology (2009) 150:5549-56. doi: 10.1210/en.2009-0775

102. Caraty A, Blomenröhr M, Vogel GMT, Lomet D, Briant C, Beltramo M. RF9 Powerfully Stimulates Gonadotrophin Secretion in the Ewe: Evidence for a Seasonal Threshold of Sensitivity. J Neuroendocrinol (2012) 24:725-36. doi: 10.1111/j.1365-2826.2012.02283.x

103. Kim JS, Brownjohn PW, Dyer BS, Beltramo M, Walker CS, Hay DL, et al. Anxiogenic and Stressor Effects of the Hypothalamic Neuropeptide RFRP-3 are Overcome by the NPFFR Antagonist GJ14. Endocrinology (2015) 156:4152-62. doi: 10.1210/en.2015-1532

104. Elhabazi K, Humbert JP, Bertin I, Quillet R, Utard V, Schneider S, et al. RF313, an Orally Bioavailable Neuropeptide FF Receptor Antagonist, Opposes Effects of RF-Amide-Related Peptide-3 and Opioid-Induced Hyperalgesia in Rodents. Neuropharmacology (2017) 118:188-98. doi: 10.1016/j.neuropharm.2017.03.012

105. Voigt C, Bennett NC. Reproductive Status-Dependent Kisspeptin and RFamide-Related Peptide (Rfrp) Gene Expression in Female Damaraland Mole-Rats. J Neuroendocrinol (2018) 30:1-9. doi: 10.1111/jne.12571

106. Frisch RE, McArthur JW. Menstrual Cycles: Fatness as a Determinant of Minimum Weight for Height Necessary for Their Maintenance or Onset. Am Assoc Adv Sci (1974) 185:949-51. doi: 10.1126/science.185.4155.949

107. Rizwan MZ, Porteous R, Herbison AE, Anderson GM. Cells Expressing RFamide-Related Peptide-1/3, the Mammalian Gonadotropin-Inhibitory Hormone Orthologs, are Not Hypophysiotropic Neuroendocrine Neurons in the Rat. Endocrinology (2009) 150:1413-20. doi: 10.1210/en.2008-1287

108. Murakami M, Matsuzaki T, Iwasa T, Yasui T, Irahara M, Osugi T, et al. Hypophysiotropic Role of RFamide-Related Peptide-3 in the Inhibition of LH Secretion in Female Rats. J Endocrinol (2008) 199:105-12. doi: 10.1677/ JOE-08-0197

109. Calisi RM, Geraghty AC, Avila A, Kaufer D, Bentley GE, Wingfield JC. Patterns of Hypothalamic GnIH Change Over the Reproductive Period in Starlings and Rats. Gen Comp Endocrinol (2016) 237:140-6. doi: 10.1016/ j.ygcen.2016.08.015

110. Connor J, Davis H. Postpartum Estrus in Norway Rats. II. Physiol Biol Reprod (1980) 23:1000-6. doi: 10.1095/biolreprod23.5.1000

111. Connor J, Davis H. Postpartum Estrus in Norway Rats. I. Behav Biol Reprod (1980) 23:994-9. doi: 10.1095/biolreprod23.5.994

112. Lee JH, Miele ME, Hicks DJ, Phillips KK, Trent JM, Weissman BE, et al. KiSS-1, a Novel Human Malignant Melanoma Metastasis-Suppressor Gene. J Natl Cancer Inst (1996) 88:1731-7. doi: 10.1093/jnci/88.23.1731

113. Lee DK, Nguyen T, O’Neill GP, Cheng R, Liu Y, Howard AD, et al. Discovery of a Receptor Related to the Galanin Receptors. FEBS Lett (1999) 446:103-7. doi: 10.1016/S0014-5793(99)00009-5
114. Irwig MS, Fraley GS, Smith JT, Acohido BV, Popa SM, Cunningham MJ, et al. Kisspeptin Activation of Gonadotropin Releasing Hormone Neurons and Regulation of KiSS-1 mRNA in the Male Rat. Neuroendocrinology (2004) 80:264-72. doi: 10.1159/000083140

115. Han SK, Gottsch ML, Lee KJ, Popa SM, Smith JT, Jakawich SK, et al. Activation of Gonadotropin-Releasing Hormone Neurons by Kisspeptin as a Neuroendocrine Switch for the Onset of Puberty. J Neurosci (2005) 25:11349-56. doi: 10.1523/JNEUROSCI.3328-05.2005

116. Messager S, Chatzidaki EE, Ma D, Hendrick AG, Zahn D, Dixon J, et al. Kisspeptin Directly Stimulates Gonadotropin-Releasing Hormone Release via G Protein-Coupled Receptor 54. Proc Natl Acad Sci USA (2005) 102:1761-6. doi: 10.1073/pnas.0409330102

117. Clarkson J, Herbison AE. Postnatal Development of Kisspeptin Neurons in Mouse Hypothalamus; Sexual Dimorphism and Projections to Gonadotropin-Releasing Hormone Neurons. Endocrinology (2006) 147:5817-25. doi: 10.1210/en.2006-0787

118. Tena-Sempere M. GPR54 and Kisspeptin in Reproduction. Hum Reprod Update (2006) 12:631-9. doi: 10.1093/humupd/dml023

119. Yeo SH, Clarkson J, Herbison AE. Kisspeptin-Gpr54 Signaling at the GnRH Neuron is Necessary for Negative Feedback Regulation of Luteinizing Hormone Secretion in Female Mice. Neuroendocrinology (2014) 100:1917. doi: $10.1159 / 000368608$

120. Moore AM, Coolen LM, Porter DT, Goodman RL, Lehman MN. KNDy Cells Revisited. Endocrinology (2018) 159:3219-34. doi: 10.1210/en.2018-00389

121. Poling MC, Quennell JH, Anderson GM, Kauffman AS. Kisspeptin Neurones do Not Directly Signal to RFRP-3 Neurones But RFRP-3 may Directly Modulate a Subset of Hypothalamic Kisspeptin Cells in Mice. J Neuroendocrinol (2013) 25:876-86. doi: 10.1111/jne.12084

122. Kiyohara M, Son YL, Tsutsui K. Involvement of Gonadotropin-Inhibitory Hormone in Pubertal Disorders Induced by Thyroid Status. Sci Rep (2017) 7:1-10. doi: 10.1038/s41598-017-01183-8

123. León S, García-Galiano D, Ruiz-Pino F, Barroso A, Manfredi-Lozano M, Romero-Ruiz A, et al. Physiological Roles of Gonadotropin-Inhibitory Hormone Signaling in the Control of Mammalian Reproductive Axis: Studies in the NPFF1 Receptor Null Mouse. Endocrinology (2014) 155:2953-65. doi: 10.1210/en.2014-1030

124. Dungan HM, Gottsch ML, Zeng H, Gragerov A, Bergmann JE, Vassilatis DK, et al. The Role of Kisspeptin-GPR54 Signaling in the Tonic Regulation and Surge Release of Gonadotropin-Releasing Hormone/Luteinizing Hormone. J Neurosci (2007) 27:12088-95. doi: 10.1523/JNEUROSCI.274807.2007

125. Martinez-Chavez CC, Minghetti M, Migaud H. GPR54 and Rgnrh I Gene Expression During the Onset of Puberty in Nile Tilapia. Gen Comp Endocrinol (2008) 156:224-33. doi: 10.1016/j.ygcen.2008.01.019

126. Revel FG, Saboureau M, Masson-Pévet M, Pévet P, Mikkelsen JDD, Simonneaux V. Kisspeptin Mediates the Photoperiodic Control of Reproduction in Hamsters. Curr Biol (2006) 16:1730-5. doi: 10.1016/ j.cub.2006.07.025

127. Greives TJ, Mason AO, Scotti MAL, Levine J, Ketterson ED, Kriegsfeld LJ, et al. Environmental Control of Kisspeptin: Implications for Seasonal Reproduction. Endocrinology (2007) 148:1158-66. doi: 10.1210/en.20061249

128. Mason AO, Greives TJ, Scotti MAL, Levine J, Frommeyer S, Ketterson ED, et al. Suppression of Kisspeptin Expression and Gonadotropic Axis Sensitivity Following Exposure to Inhibitory Day Lengths in Female Siberian Hamsters. Horm Behav (2007) 52:492-8. doi: 10.1016/ j.yhbeh.2007.07.004

129. Piekarski D, Jarjisian S, Perez L, Ahmad H, Dhawan N, Zucker I, et al. Effects of Pinealectomy and Short Day Lengths on Reproduction and Neuronal RFRP-3, Kisspeptin, and GnRH in Female Turkish Hamsters. J Biol Rhythm (2014) 29:181-91. doi: 10.1177/0748730414532423

130. Wahab F, Atika B, Shahab M. Kisspeptin as a Link Between Metabolism and Reproduction: Evidences From Rodent and Primate Studies. Metabolism (2013) 62:898-910. doi: 10.1016/j.metabol.2013.01.015

131. Harter CJL, Kavanagh GS, Smith JT. The Role of Kisspeptin Neurons in Reproduction and Metabolism. J Endocrinol (2018) 238:R173-83. doi: 10.1530/JOE-18-0108 
132. Paul MJ, Pyter LM, Freeman DA, Galang J, Prendergast BJ. Photic and Nonphotic Seasonal Cues Differentially Engage Hypothalamic Kisspeptin and RFamide-Related Peptide mRNA Expression in Siberian Hamsters. J Neuroendocrinol (2009) 21:1007-14. doi: 10.1111/j.1365-2826.2009.01924.x

133. Hanlon C, Ramachandran R, Zuidhof MJ, Bedecarrats GY. Should I Lay or Should I Grow: Photoperiodic Versus Metabolic Cues in Chickens. Front Physiol (2020) 11:707. doi: 10.3389/fphys.2020.00707

134. Um HN, Han JM, Hwang JI, Hong SI, Vaudry H, Seong JY. Molecular Coevolution of Kisspeptins and Their Receptors From Fish to Mammals. Ann N Y Acad Sci (2010) 1200:67-74. doi: 10.1111/j.1749-6632.2010.05508.x

135. Joseph NT, Tello JA, Bedecarrats GY, Millar RP. Reproductive Neuropeptides: Prevalence of GnRH and KNDy Neural Signalling Components in a Model Avian, Gallus Gallus. Gen Comp Endocrinol (2012) 190:134-43. doi: 10.1016/j.ygcen.2013.05.018

136. Ronnekleiv O, Ojeda S, Mccann SM. Undernutrition, Puberty and the Development of Estrogen Positive Feedback Female Rat. Biol Reprod (1978) 19:414-24. doi: 10.1095/biolreprod19.2.414

137. Dunnington EA, Siegel PB, Cherry JA, Soller M. Relationship of Age and Body Weight at Sexual Maturity in Selected Lines of Chickens. Arch Geflugelkd (1983) 47:85-9.

138. Dunnington EA, Siegel PB. Age and Body Weight at Sexual Maturity in Female White Leghorn Chickens. Poult Sci (1984) 63:828-30. doi: 10.3382/ ps.0630828

139. Zelenka DJ, Cherry JA, Nir I, Siegel PB. Body Weight and Composition of Japanese Quail (Coturnix Coturnix Japonica) at Sexual Maturity. Growth (1984) 48:16-28.

140. Lewis PD, Perry GC, Morris TR. Effect of Size and Timing of Photoperiod Increase on Age at First Egg and Subsequent Performance of Two Breeds of Laying Hen. Br Poult Sci (1997) 38:142-50. doi: 10.1080/00071669708417959

141. Hanlon C, Takeshima K, Bédécarrats GY. Changes in the Control of the Hypothalamic-Pituitary Gonadal Axis Across Three Differentially Selected Strains of Laying Hens (Gallus Gallus Domesticus). Front Physiol (2021) 12. doi: 10.3389/fphys.2021.651491

142. Anjum S, Krishna A, Tsutsui K. Possible Role of GnIH as a Mediator Between Adiposity and Impaired Testicular Function. Front Endocrinol (Lausanne) (2016) 7:1-12. doi: 10.3389/fendo.2016.00006

143. Moriwaki S, Narimatsu Y, Fukumura K, Iwakoshi-Ukena E, Furumitsu M, Ukena K. Effects of Chronic Intracerebroventricular Infusion of RfamideRelated Peptide-3 on Energy Metabolism in Male Mice. Int J Mol Sci (2020) 21:1-15. doi: 10.3390/ijms21228606

144. Sridaran R, Smith CJ, Richards JAS. Effects of In Vivo Dihydrotestosterone Treatment on Changes in Nocturnal Surge of Prolactin, Luteal Ultrastructure and P-450scc mRNA and Protein Content in Pregnant Rats. Mol Cell Endocrinol (1991) 77:75-83. doi: 10.1016/0303-7207(91)90060-6

145. Clark JT, Kalra PS, Crowley WR, Kalra SP. Neuropeptide Y and Human Pancreatic Polypeptide Stimulate Feeding Behaviour in Rats. Endocrinology (1984) 115:427-9. doi: 10.1210/endo-115-1-427

146. Contijoch A, Malamed S, McDonald J, Advis J. Neuropeptide Y Regulation of LHRH Release in the Median Eminence: Immunocytochemical and Physiological Evidence in Hens. Neuroendocrinology (1993) 57:135-45. doi: $10.1159 / 000126353$

147. Kriegsfeld LJ, Jennings KJ, Bentley GE, Tsutsui K. Gonadotrophin-Inhibitory Hormone and its Mammalian Orthologue RFamide-Related Peptide-3: Discovery and Functional Implications for Reproduction and Stress. J Neuroendocrinol (2018) 30:1-13. doi: 10.1111/jne.12597

148. Poling MC, Shieh MP, Munaganuru N, Luo E, Kauffman AS. Examination of the Influence of Leptin and Acute Metabolic Challenge on RFRP-3 Neurons of Mice in Development and Adulthood. Neuroendocrinology (2014) 100:317-33. doi: 10.1159/000369276

149. Zelenka DJ, Siegel PB, Dunnington EA, Cherry JA. Inheritance of Traits Associated With Sexual Maturity When Populations of Chickens Reach 50\% Lay. Poult Sci (1986) 65:233-40. doi: 10.3382/ps.0650233

150. van der Klein SAS, Bédécarrats GY, Robinson FE, Zuidhof MJ. Early Photostimulation at the Recommended Body Weight Reduced Broiler Breeder Performance. Poult Sci (2018) 97:3736-45. doi: 10.3382/ps/pey215

151. Hocking PM, Bernard R, Robertson GW. Effects of Low Dietary Protein and Different Allocations of Food During Rearing and Restricted Feeding After Peak Rate of Lay on Egg Production, Fertility and Hatchability in Female
Broiler Breeders. Br Poult Sci (2002) 43:94-103. doi: 10.1080/ 00071660120109908

152. Walzem RL, Chen S. Obesity-Induced Dysfunctions in Female Reproduction: Lessons From Birds and Mammals. Adv Nutr (2014) 5:199-206. doi: 10.3945/an.113.004747

153. Huo K, Li X, Hu W, Song X, Zhang D, Zhang X, et al. RFRP-3, the Mammalian Ortholog of GnIH, Is a Novel Modulator Involved in Food Intake and Glucose Homeostasis. Front Endocrinol (Lausanne) (2020) 11:115. doi: 10.3389/fendo.2020.00194

154. Andreoli MF, Stoker C, Rossetti MF, Alzamendi A, Castrogiovanni D, Luque EH, et al. Withdrawal of Dietary Phytoestrogens in Adult Male Rats Affects Hypothalamic Regulation of Food Intake, Induces Obesity and Alters Glucose Metabolism. Mol Cell Endocrinol (2015) 401:111-9. doi: 10.1016/ j.mce.2014.12.002

155. Morton GJ, Schwartz MW. The NPY/AgRP Neuron and Energy Homeostasis. Int J Obes (2001) 25:S56-62. doi: 10.1038/sj.ijo.0801915

156. Phillips-Singh D, Li Q, Takeuchi S, Ohkubo T, Sharp P, Boswell T. Fasting Differentially Regulates Expression of Agouti-Related Peptide, ProOpiomelanocortin, Prepro-Orexin, and Vasoactive Intestinal Polypeptide mRNAs in the Hypothalamus of Japanese Quail. Cell Tissue Res (2003) 313:217-25. doi: 10.1007/s00441-003-0755-8

157. Millington GWM. The Role of Proopiomelanocortin (POMC) Neurones in Feeding Behaviour. Nutr Metab (2007) 4:1-16. doi: 10.1186/1743-7075-4-18

158. Higgins SE, Ellestad LE, Trakooljul N, McCarthy F, Saliba J, Cogburn LA, et al. Transcriptional and Pathway Analysis in the Hypothalamus of Newly Hatched Chicks During Fasting and Delayed Feeding. BMC Genomics (2010) 11:1-17. doi: 10.1186/1471-2164-11-162

159. Hill J. Gene Expression and the Control of Food Intake by Hypothalamix POMC/CART Neurons. Open Neuroendocrinol (2010) 3:21-7.

160. Song Z, Liu L, Sheikhahmadi A, Jiao H, Lin H. Effect of Heat Exposure on Gene Expression of Feed Intake Regulatory Peptides in Laying Hens. J Biomed Biotechnol (2012) 2012:1-8. doi: 10.1155/2012/484869

161. Jacobi JS, Coleman HA, Enriori PJ, Parkington HC, Li Q, Pereira A, et al. Paradoxical Effect of Gonadotrophin-Inhibiting Hormone to Negatively Regulate Neuropeptide Y Neurones in Mouse Arcuate Nucleus. J Neuroendocrinol (2013) 25:1308-17. doi: 10.1111/jne.12114

162. Gospodarska E, Kozak LP, Jaroslawska J. Isolation and Identification of Endogenous RFamide-Related Peptides 1 and 3 in the Mouse Hypothalamus. J Neuroendocrinol (2019) 31:1-10. doi: 10.1111/jne.12668

163. Qi Y, Oldfield BJ, Clarke IJ. Projections of RFamide-Related Peptide-3 Neurones in the Ovine Hypothalamus, With Special Reference to Regions Regulating Energy Balance and Reproduction. J Neuroendocrinol (2009) 21:690-7. doi: 10.1111/j.1365-2826.2009.01886.x

164. Fu LY, Van Den Pol AN. Kisspeptin Directly Excites Anorexigenic Proopiomelanocortin Neurons But Inhibits Orexigenic Neuropeptide Y Cells by an Indirect Synaptic Mechanism. J Neurosci (2010) 30:10205-19. doi: 10.1523/JNEUROSCI.2098-10.2010

165. McConn B, Wang G, Yi J, Gilbert ER, Osugi T, Ubuka T, et al. Gonadotropin-Inhibitory Hormone-Stimulation of Food Intake is Mediated by Hypothalamic Effects in Chicks. Neuropeptides (2014) 48:327-34. doi: 10.1016/j.npep.2014.09.001

166. Clarke IJ, Smith JT, Henry BA, Oldfield BJ, Stefanidis A, Millar RP, et al. Gonadotropin-Inhibitory Hormone is a Hypothalamic Peptide That Provides a Molecular Switch Between Reproduction and Feeding. Neuroendocrinology (2012) 95:305-16. doi: 10.1159/000332822

167. Fraley GS, Coombs E, Gerometta E, Colton S, Sharp PJ, Li Q, et al. Distribution and Sequence of Gonadotropin-Inhibitory Hormone and its Potential Role as a Molecular Link Between Feeding and Reproductive Systems in the Pekin Duck (Anas Platyrhynchos Domestica). Gen Comp Endocrinol (2013) 184:103-10. doi: 10.1016/j.ygcen.2012.11.026

168. Tachibana T, Sato M, Takahashi H, Ukena K, Tsutsui K, Furuse M. Gonadotropin-Inhibiting Hormone Stimulates Feeding Behavior in Chicks. Brain Res (2005) 1050:94-100. doi: 10.1016/j.brainres.2005.05.035

169. Hill JW, Alreja M, Elias CF. From Precocious Puberty to Infertility: Metabolic Control of the Reproductive Function. Front Endocrinol (Lausanne) (2013) 4:2012-3. doi: 10.3389/fendo.2013.00043

170. Wilsterman K, Alonge MM, Bao X, Conner KA, Bentley GE. Food Access Modifies GnIH, But Not CRH, Cell Number in the Hypothalamus in a 
Female Songbird. Gen Comp Endocrinol (2020) 292:113438. doi: 10.1016/ j.ygcen.2020.113438

171. Ciccone NA, Dunn IC, Sharp PJ. Increased Food Intake Stimulates GnRH-I, Glycoprotein Hormone $\alpha$-Subunit and Follistatin mRNAs, and Ovarian Follicular Numbers in Laying Broiler Breeder Hens. Domest Anim Endocrinol (2007) 33:62-76. doi: 10.1016/j.domaniend.2006.04.008

172. Lynn SE, Perfito N, Guardado D, Bentley GE. Food, Stress, and Circulating Testosterone: Cue Integration by the Testes, Not the Brain, in Male Zebra Finches (Taeniopygia Guttata). Gen Comp Endocrinol (2015) 215:1-9. doi: 10.1016/j.ygcen.2015.03.010

173. Mercer JG, Hoggard N, Williams LM, Bruce Lawrence C, Hannah LT, Morgan PJ, et al. Coexpression of Leptin Receptor and Preproneuropeptide Y mRNA in Arcuate Nucleus of Mouse Hypothalamus. J Neuroendocrinol (1996) 8:733-5. doi: 10.1046/j.1365-2826.1996.05161.x

174. Cheung C, Clifton D, Steiner R. Proopiomelanocortin Neurons are Direct Targets for Leptin in the Hypothalamus. Endocrinology (1997) 138:4489-92. doi: 10.1210/endo.138.10.5570

175. Anjum S, Khattak MNK, Tsutsui K, Krishna A. RF-Amide Related Peptide-3 (RFRP-3): A Novel Neuroendocrine Regulator of Energy Homeostasis, Metabolism, and Reproduction. Mol Biol Rep (2021) 48:1837-52. doi: 10.1007/s11033-021-06198-z

176. Ozcan M, Saatci T, Ayar A, Canpolat S, Kelestimur H. Leptin Activates Cytosolic Calcium Responses Through Protein Kinase-C Dependent Mechanism in Immortalized RFamide-Related Peptide-3 Neurons. Brain Res (2015) 1601:8-14. doi: 10.1016/j.brainres.2014.12.053

177. Quennell JH, Mulligan AC, Tups A, Liu X, Phipps SJ, Kemp CJ, et al. Leptin Indirectly Regulates Gonadotropin-Releasing Hormone Neuronal Function. Endocrinology (2009) 150:2805-12. doi: 10.1210/en.2008-1693

178. Benton NA, Russo KA, Brozek JM, Andrews RJ, Kim VJ, Kriegsfeld LJ, et al. Food Restriction-Induced Changes in Motivation Differ With Stages of the Estrous Cycle and are Closely Linked to RFamide-Related Peptide-3 But Not Kisspeptin in Syrian Hamsters. Physiol Behav (2018) 190:43-60. doi: 10.1016/j.physbeh.2017.06.009

179. Swerdloff RS, Peterson M, Vera A, Batt RAL, Heber D, Bray GA. The Hypothalamic-Pituitary Axis in Genetically Obese (Ob/Ob) Mice: Response to Luteinizing Hormone-Releasing Hormone. Endocrinology (1978) 103:542-7. doi: 10.1210/endo-103-2-542

180. Barash IA, Cheung CC, Weigle DS, Ren H, Kabigting EB, Kuijper JL, et al. Leptin is a Metabolic Signal to the Reproductive System. Endocrinology (1996) 137:3144-7. doi: 10.1210/endo.137.7.8770941

181. Chehab F, Lim M, Lu R. Correction of the Sterility Defect in Homozygous Obses Female Mice by Treatment With the Human Recombinant Leptin. Nat Genet (1996) 12:318-20. doi: 10.1038/ng0396-318

182. Pelleymounter MA, Cullen MJ, Baker MB, Hecht R, Winters D, Boone T, et al. Effects of the Obese Gene Product on Body Weight Regulation in Ob/Ob Mice. Sci (80-) (1995) 269:540-3. doi: 10.1126/ science.7624776

183. Campfield LA, Smith FJ, Guisez Y, Devos R, Burn P. OB Protein: A Peripheral Signal Linking Adiposity and Central Neural Networks. Appetite (1996) 26:302. doi: 10.1006/appe.1996.0024

184. Ahima RS, Dushay J, Flier SN, Prabakaran D, Flier JS. Leptin Accelerates the Onset of Puberty in Normal Female Mice. J Clin Invest (1997) 99:391-5. doi: 10.1172/JCI119172

185. Niswender K, Morton G, Sterns W, Rhodes C, Myers M, Schwartz M. Key Enzyme in Leptin-Induced Anorexia. Nature (2001) 413:794-5. doi: 10.1038/ 35101657

186. Zhang W, Wang L, Yu X, Jia A, Ming J, Ji Q. RFamide-Related Peptide-3 Promotes Alpha TC1 Clone 6 Cell Survival Likely via GPR147. Peptides (2018) 107:39-44. doi: 10.1016/j.peptides.2018.07.009

187. Celik O, Celik N, Aydin S, Aygun BK, Haberal ET, Kuloglu T, et al. Ghrelin Action on GnRH Neurons and Pituitary Gonadotropes Might be Mediated by GnIH-GPR147 System. Horm Mol Biol Clin Investig (2016) 25:121-8. doi: 10.1515/hmbci-2015-0050

188. Farkas I, Vastagh C, Sárvári M, Liposits Z. Ghrelin Decreases Firing Activity of Gonadotropin-Releasing Hormone (GnRH) Neurons in an Estrous Cycle and Endocannabinoid Signaling Dependent Manner. PloS One (2013) 8:116. doi: 10.1371/journal.pone.0078178
189. Kaiya H, van der Geyten S, Kojima M, Hosoda H, Kitajima Y, Matsumoto M, et al. Chicken Ghrelin: Purification, cDNA Cloning, and Biological Activity. Endocrinology (2002) 143:3454-63. doi: 10.1210/en.2002-220255

190. Lu S, Guan JL, Wang QP, Uehara K, Yamada S, Goto N, et al. Immunocytochemical Observation of Ghrelin-Containing Neurons in the Rat Arcuate Nucleus. Neurosci Lett (2002) 321:157-60. doi: 10.1016/S03043940(01)02544-7

191. Wang L, Saint-Pierre DH, Taché Y. Peripheral Ghrelin Selectively Increases Fos Expression in Neuropeptide Y - Synthesizing Neurons in Mouse Hypothalamic Arcuate Nucleus. Neurosci Lett (2002) 325:47-51. doi: 10.1016/S0304-3940(02)00241-0

192. Tena-Sempere M. Ghrelin and Reproduction: Ghrelin as Novel Regulator of the Gonadotropic Axis. Vitam Horm (2008) 77:285-300. doi: 10.1016/S00836729(06)77012-1

193. Tena-Sempere M, Barreriro M, Gonzalez L, Gaytan F, Zhang F, Caminos J, et al. Novel Expression and Functional Role of Ghrelin in Rat Testis. Endocrinology (2002) 143:717-25. doi: 10.1210/endo.143.2.8646

194. Kaiya H, Kangawa K, Miyazato M. Update on Ghrelin Biology in Birds. Gen Comp Endocrinol (2013) 190:170-5. doi: 10.1016/j.ygcen.2013.04.014

195. Perez-Tilve D, Heppner K, Kirchner H, Lockie SH, Woods SC, Smiley DL, et al. Ghrelin-Induced Adiposity is Independent of Orexigenic Effects. FASEB J (2011) 25:2814-22. doi: 10.1096/fj.11-183632

196. Bentley GE, Wilsterman K, Ernst DK, Lynn SE, Dickens MJ, Calisi RM, et al. Neural Versus Gonadal Gnih: Are They Independent Systems? A MiniReview. Integr Comp Biol (2017) 57:1194-203. doi: 10.1093/icb/icx085

197. Salem MHM, Norton HW, Nalbandov AV. The Role of Vasotocin and of CRF in ACTH Release in the Chicken. Gen Comp Endocrinol (1970) 14:2819. doi: 10.1016/0016-6480(70)90056-0

198. Carsia RV, Weber H, Perez FM. Corticotropin-Releasing Factor Stimulates the Release of Adrenocorticotropin From Domestic Fowl Pituitary Cells. Endocrinology (1986) 118:143-8. doi: 10.1210/endo-118-1-143

199. Kirby ED, Geraghty AC, Ubuka T, Bentley GE, Kaufer D. Stress Increases Putative Gonadotropin Inhibitory Hormone and Decreases Luteinizing Hormone in Male Rats. Proc Natl Acad Sci USA (2009) 106:11324-9. doi: 10.1073/pnas.0901176106

200. Soga T, Dalpatadu SL, Wong DW, Parhar IS. Neonatal Dexamethasone Exposure Down-Regulates GnRH Expression Through the GnIH Pathway in Female Mice. Neuroscience (2012) 218:56-64. doi: 10.1016/j.neuroscience. 2012.05.023

201. Son YL, Ubuka T, Narihiro M, Fukuda Y, Hasunuma I, Yamamoto K, et al. Molecular Basis for the Activation of Gonadotropin-Inhibitory Hormone Gene Transcription by Corticosterone. Endocrinology (2014) 155:1817-26. doi: 10.1210/en.2013-2076

202. Iwasa T, Matsuzaki T, Tungalagsuvd A, Munkhzaya M, Kawami T, Niki H, et al. Hypothalamic Kiss1 and RFRP Gene Expressions are Changed by a High Dose of Lipopolysaccharide in Female Rats. Horm Behav (2014) 66:309-16. doi: 10.1016/j.yhbeh.2014.06.007

203. Higuchi Y, Soga T, Parhar IS. Social Defeat Stress Decreases mRNA for Monoamine Oxidase A and Increases 5-HT Turnover in the Brain of Male Nile Tilapia (Oreochromis Niloticus). Front Pharmacol (2019) 9:1-9. doi: 10.3389/fphar.2018.01549

204. Thomas FSK, Higuchi Y, Ogawa S, Soga T, Parhar IS. Acute Social Defeat Stress Upregulates Gonadotrophin Inhibitory Hormone and its Receptor But Not Corticotropin-Releasing Hormone and ACTH in the Male Nile Tilapia (Oreochromis Niloticus). Peptides (2021) 138:170504. doi: 10.1016/ j.peptides.2021.170504

205. Soga T, Teo CH, Cham KL, Idris MM, Parhar IS. Early-Life Social Isolation Impairs the Gonadotropin-Inhibitory Hormone Neuronal Activity and Serotonergic System in Male Rats. Front Endocrinol (Lausanne) (2015) 6:1-11. doi: 10.3389/fendo.2015.00172

206. Sánchez M, Aguado F, Sánchez-Toscano F, Saphier D. Neuroendocrine and Immunocytochemical Demonstrations of Decreased HypothalamoPituitary-Adrenal Axis Responsiveness to Restraint Stress After LongTerm Social Isolation. Endocrinology (1998) 139:579-87. doi: 10.1210/ endo.139.2.5720

207. Ogawa S, Sivalingam M, Biran J, Golan M, Anthonysamy RS, Levavi-Sivan B, et al. Distribution of LPXRFa, a Gonadotropin-Inhibitory Hormone 
Ortholog Peptide, and LPXRFa Receptor in the Brain and Pituitary of the Tilapia. J Comp Neurol (2016) 524:2753-75. doi: 10.1002/cne.23990

208. Kaewwongse M, Takayanagi Y, Onaka T. Effects of RFamide-Related Peptide (RFRP)-1 and RFRP-3 on Oxytocin Release and Anxiety-Related Behaviour in Rats. J Neuroendocrinol (2011) 23:20-7. doi: 10.1111/j.1365-2826.2010.02077.x

209. Gojska NM, Belsham DD. Glucocorticoid Receptor-Mediated Regulation of Rfrp (GnIH) and Gpr147 (GnIH-R) Synthesis in Immortalized Hypothalamic Neurons. Mol Cell Endocrinol (2014) 384:23-31. doi: 10.1016/j.mce.2013.12.015

210. Calisi RM, Austin SH, Lang AS, MacManes MD. Sex-Biased Transcriptomic Response of the Reproductive Axis to Stress. Horm Behav (2018) 100:56-68. doi: 10.1016/j.yhbeh.2017.11.011

211. Bjergved L, Jørgensen T, Perrild H, Laurberg P, Krejbjerg A, Ovesen L, et al. Thyroid Function and Body Weight: A Community-Based Longitudinal Study. PloS One (2014) 9:7-13. doi: 10.1371/journal.pone.0093515

212. Ríos-Prego M, Anibarro L, Sánchez-Sobrino P. Relationship Between Thyroid Dysfunction and Body Weight: A Not So Evident Paradigm. Int $J$ Gen Med (2019) 12:299-304. doi: 10.2147/IJGM.S206983

213. López M, Varela L, Vázquez MJ, Rodríguez-Cuenca S, González CR, Velagapudi VR, et al. Hypothalamic AMPK and Fatty Acid Metabolism Mediate Thyroid Regulation of Energy Balance. Nat Med (2010) 16:1001-8. doi: $10.1038 / \mathrm{nm} .2207$

214. Motomura K, Brent G. Mechanisms of Thyroid Hormone Action: Implcations for the Clinical Manifestation of Thyrotoxicosis. Endocrinol Metab Clincis North Am (1998) 27:1-23. doi: 10.1016/S0889-8529(05) 70294-2

215. Brent GA. Graves 'Disease. New Engl J Med (2008) 358:2594-605. doi: 10.1056/NEJMcp0801880

216. Boelen A, Kwakkel J, Vos XG, Wiersinga WM, Fliers E. Differential Effects of Leptin and Refeeding on the Fasting-Induced Decrease of Pituitary Type 2 Deiodinase and Thyroid Hormone Receptor $\beta 2$ mRNA Expression in Mice. J Endocrinol (2006) 190:537-44. doi: 10.1677/joe.1.06872

217. Coppola A, Liu ZW, Andrews ZB, Paradis E, Roy MC, Friedman JM, et al. A Central Thermogenic-Like Mechanism in Feeding Regulation: An Interplay Between Arcuate Nucleus T3 and UCP2. Cell Metab (2007) 5:21-33. doi: 10.1016/j.cmet.2006.12.002

218. Reinehr T. Obesity and Thyroid Function. Mol Cell Endocrinol (2010) 316:165-71. doi: 10.1016/j.mce.2009.06.005

219. Langouche L, Vander Perre S, Marques M, Boelen A, Wouters PJ, Casaer MP, et al. Impact of Early Nutrient Restriction During Critical Illness on the Nonthyroidal Illness Syndrome and its Relation With Outcome: A Randomized, Controlled Clinical Study. J Clin Endocrinol Metab (2013) 98:1006-13. doi: 10.1210/jc.2012-2809

220. Ahima RS, Prabakaran D, Mantzoros C, Qu D, Lowell B, Maratos-Flier E, et al. Role of Leptin in the Neuroendocrine Response to Fasting. Nature (1996) 382:250-2. doi: 10.1038/382250a0

221. Fekete C, Légrádi G, Mihály E, Huang QH, Tatro JB, Rand WM, et al. $\alpha$-Melanocyte-Stimulating Hormone Is Contained in Nerve Terminals Innervating Thyrotropin-Releasing Hormone-Synthesizing Neurons in the Hypothalamic Paraventricular Nucleus and Prevents Fasting-Induced Suppression of Prothyrotropin-Releasing Hormone Gene E. J Neurosci (2000) 20:1550-8. doi: 10.1523/JNEUROSCI.20-0401550.2000

222. Seoane LM, Carro E, Tovar S, Casanueva FF, Dieguez C. Regulation of In Vivo TSH Secretion by Leptin. Regul Pept (2000) 92:25-9. doi: 10.1016/ S0167-0115(00)00145-2

223. Costa da Veiga MAL, de Jesus Oliveira K, Curty FH, Pazos de Moura CC. Thyroid Hormones Modulate the Endocrine and Autocrine/Paracrine Actions of Leptin on Thyrotropin Secretion. J Endocrinol (2004) 183:2437. doi: $10.1677 /$ joe.1.05746

224. Oge A, Bayraktar F, Saygili F, Guney E, Demir S. TSH Influences Serum Leptin Levels Independent of Thyroid Hormones in Hypothyroid and Hyperthyroid Patients. Endocr J (2005) 52:213-7. doi: 10.1507/ endocr.j.52.213

225. Perello M, Çakir I, Cyr NE, Romero A, Stuart RC, Chiappini F, et al. Maintenance of the Thyroid Axis During Diet-Induced Obesity in Rodents is Controlled at the Central Level. Am J Physiol Endocrinol Metab (2010) 299:976-89. doi: 10.1152/ajpendo.00448.2010
226. Prevot V, Croix D, Bouret S, Dutoit S, Tramu G, Stefano GB, et al. Definitive Evidence for the Existence of Morphological Plasticity in the External Zone of the Median Eminence During the Rat Estrous Cycle: Implication of NeuroGlio-Endothelial Interactions in Gonadotropin-Releasing Hormone Release. Neuroscience (1999) 94:809-19. doi: 10.1016/S0306-4522(99)00383-8

227. Yamamura T, Hirunagi K, Ebihara S, Yoshimura T. Seasonal Morphological Changes in the Neuro-Glial Interaction Between Gonadotropin-Releasing Hormone Nerve Terminals and Glial Endfeet in Japanese Quail. Endocrinology (2004) 145:4264-7. doi: 10.1210/en.2004-0366

228. Yamamura T, Yasuo S, Hirunagi K, Ebihara S, Yoshimura T. T3 Implantation Mimics Photoperiodically Reduced Encasement of Nerve Terminals by Glial Processes in the Median Eminence of Japanese Quail. Cell Tissue Res (2006) 324:175-9. doi: 10.1007/s00441-005-0126-8

229. Lin Y, Sun Z. Thyroid Hormone Potentiates Insulin Signaling and Attenuates Hyperglycemia and Insulin Resistance in a Mouse Model of Type 2 Diabetes. Br J Pharmacol (2011) 162:597-610. doi: 10.1111/j.14765381.2010.01056.x

230. Maddeineni S, Ocon-Grove O, Krzysik-Walker S, Hendricks G, Proudman JA, Ramachandran R. Gonadotrophin-Inhibitory Hormone Receptor Expression in the Chicken Pituitary Gland: Potential Influence of Sexual Maturation and Ovarian Steroids. J Neuroendocrinol (2008) 20:1078-88. doi: 10.1111/j.1365-2826.2008.01765.x

231. Purcell SH, Moley KH. Glucose Transporters in Gametes and Preimplantation Embryos. Trends Endocrinol Metab (2009) 20:483-9. doi: 10.1016/j.tem.2009.06.006

232. Wang Q, Chi MM, Schedl T, Moley KH. An Intercellular Pathway for Glucose Transport Into Mouse Oocytes. Am J Physiol Endocrinol Metab (2012) 302:1511-8. doi: 10.1152/ajpendo.00016.2012

233. Wang P, Mariman E, Renes J, Keijer J. The Secretory Function of Adipocytes in the Physiology of White Adipose Tissue. J Cell Physiol (2008) 216:3-13. doi: $10.1002 /$ jcp. 21386

234. Chechi K, Carpentier AC, Richard D. Understanding the Brown Adipocyte as a Contributor to Energy Homeostasis. Trends Endocrinol Metab (2013) 24:408-20. doi: 10.1016/j.tem.2013.04.002

235. Zhang W, Bi S. Hypothalamic Regulation of Brown Adipose Tissue Thermogenesis and Energy Homeostasis. Front Endocrinol (Lausanne) (2015) 6. doi: 10.3389/fendo.2015.00136

236. Considine R, Sinha M, Heiman M, Kriauciunas A, Stephens T, Nyce M, et al. Serum Immunoreactive-Leptin Concentrations in Normal-Weight and Obese Humans. N Engl J Med (1996) 334:292-5. doi: 10.1056/NEJM199602013340503

237. Halaas JL, Boozer C, Blair-West J, Fidahusein N, Denton DA, Friedman JM. Physiological Response to Long-Term Peripheral and Central Leptin Infusion in Lean and Obese Mice. Proc Natl Acad Sci USA (1997) 94:8878-83. doi: 10.1073/pnas.94.16.8878

238. Friedman JM. Leptin at $14 \mathrm{Y}$ of Age: An Ongoing Story. Am J Clin Nutr (2009) 89:973-9. doi: 10.3945/ajcn.2008.26788B

239. Schneider JE, Blum RM, Wade GN. Metabolic Control of Food Intake and Estrous Cycles in Syrian Hamsters. I. Plasma Insulin and Leptin. Am J Physiol Regul Integr Comp Physiol (2000) 278:476-85. doi: 10.1152/ ajpregu.2000.278.2.R476

240. Barb CR, Yan X, Azain MJ, Kraeling RR, Rampacek GB, Ramsay TG. Recombinant Porcine Leptin Reduces Feed Intake and Stimulates Growth Hormone Secretion in Swine. Domest Anim Endocrinol (1998) 15:77-86. doi: 10.1016/S0739-7240(97)00064-7

241. Cowley MA, Smart JL, Rubinstein M, Cerdán MG, Diano S, Horvath TL, et al. Leptin Activates Anorexigenic POMC Neurons Through a Neural Network in the Arcuate Nucleus. Nature (2001) 411:480-4. doi: 10.1038/ 35078085

242. Ingalls AM, Dickie MM, Snell GD. Obese, a New Mutation in the House Mouse. J Hered (1950) 41:315-7. doi: 10.1093/oxfordjournals.jhered.a106073

243. Zhang Y, Proenca R, Maffei M, Barone M, Leopold L, Friedman J. Positional Cloning of the Mouse Obese Gene and its Human Homologue. Nature (1994) 372:425-31. doi: 10.1038/372425a0

244. Ye J. Mechanisms of Insulin Resistance in Obesity. Front Med China (2013) 7:14-24. doi: 10.1007/s11684-013-0262-6

245. Accili D. The Struggle for Mastery in Insulin Action: From Triumvirate to Republic. J Natl Med Assoc (2004) 53:1633-42. doi: 10.2337/diabetes. 53.7.1633 
246. De Marinis YZ, Salehi A, Ward CE, Zhang Q, Abdulkader F, Bengtsson M, et al. GLP-1 Inhibits and Adrenaline Stimulates Glucagon Release by Differential Modulation of $\mathrm{N}$ - and L-Type Ca2+ ChannelDependent Exocytosis. Cell Metab (2010) 11:543-53. doi: 10.1016/ j.cmet.2010.04.007

247. Tian G, Maria Sol ER, Xu Y, Shuai H, Tengholm A. Impaired cAMP Generation Contributes to Defective Glucose-Stimulated Insulin Secretion After Long-Term Exposure to Palmitate. Diabetes (2015) 64:904-15. doi: 10.2337/db14-1036

248. Schwartz MW, Figlewicz DP, Baskin DG, Woods SC, Porte D. Insulin in the Brain: A Hormonal Regulator of Energy Balance. Endocr Rev (1992) 13:387414. doi: 10.1210/edrv-13-3-387

249. Stockhorst U, De Fries D, Steingrueber HJ, Scherbaum WA. Insulin and the CNS: Effects on Food Intake, Memory, and Endocrine Parameters and the Role of Intranasal Insulin Administration in Humans. Physiol Behav (2004) 83:47-54. doi: 10.1016/S0031-9384(04)00348-8

250. Cázarez-Márquez F, Eliveld J, Ritsema WIGR, Foppen E, Bossenbroek Y, Pelizzari S, et al. Role of Central Kisspeptin and RFRP-3 in Energy Metabolism in the Male Wistar Rat. J Neuroendocrinol (2021) 33:1-15. doi: 10.1111 /jne.12973

251. Tolson KP, Garcia C, Yen S, Simonds S, Stefanidis A, Lawrence A, et al. Impaired Kisspeptin Signaling Decreases Metabolism and Promotes Glucose Intolerance and Obesity. J Clin Invest (2014) 124:3075-9. doi: 10.1172/ JCI71075
252. Crown A, Clifton DK, Steiner RA. Neuropeptide Signaling in the Integration of Metabolism and Reproduction. Neuroendocrinology (2007) 86:175-82. doi: 10.1159/000109095

253. Schneider JE, Benton NA, Russo KA, Klingerman CM, Williams WP, Simberlund J, et al. RFamide-Related Peptide-3 and the Trade-Off Between Reproductive and Ingestive Behavior. Integr Comp Biol (2017) 57:1225-39. doi: 10.1093/icb/icx097

Conflict of Interest: The authors declare that the research was conducted in the absence of any commercial or financial relationships that could be construed as a potential conflict of interest.

Publisher's Note: All claims expressed in this article are solely those of the authors and do not necessarily represent those of their affiliated organizations, or those of the publisher, the editors and the reviewers. Any product that may be evaluated in this article, or claim that may be made by its manufacturer, is not guaranteed or endorsed by the publisher.

Copyright (C) 2022 Bédécarrats, Hanlon and Tsutsui. This is an open-access article distributed under the terms of the Creative Commons Attribution License (CC BY). The use, distribution or reproduction in other forums is permitted, provided the original author(s) and the copyright owner(s) are credited and that the original publication in this journal is cited, in accordance with accepted academic practice. No use, distribution or reproduction is permitted which does not comply with these terms. 